\title{
Review \\ Unity Makes Strength: A Review on Mutualistic Symbiosis in Representative Insect Clades
}

\author{
Rosario Gil 1,2,3,*(D) and Amparo Latorre 1,2,3,* \\ 1 Institute for Integrative Systems Biology (I2SysBio), Universitat de València/CSIC. Calle Catedrático \\ Agustín Escardino, 9, 46980 Paterna (Valencia), Spain \\ 2 Departament de Genètica, Universitat de València. Calle Dr. Moliner, 50, 46100 Burjassot (València), Spain \\ 3 Área de Genómica y Salud, Fundación para el Fomento de la Investigación Sanitaria y Biomédica de la \\ Comunidad Valenciana (FISABIO). Avenida de Cataluña 21, 46020 València, Spain \\ * Correspondence: rosario.gil@uv.es (R.G.); amparo.latorre@uv.es (A.L.) Tel.: +34-96-354-3824 (R.G.); \\ +34-96-354-4649 (A.L.)
}

Received: 11 December 2018; Accepted: 19 February 2019; Published: 25 February 2019

\begin{abstract}
Settled on the foundations laid by zoologists and embryologists more than a century ago, the study of symbiosis between prokaryotes and eukaryotes is an expanding field. In this review, we present several models of insect-bacteria symbioses that allow for the detangling of most known features of this distinctive way of living, using a combination of very diverse screening approaches, including molecular, microscopic, and genomic techniques. With the increasing the amount of endosymbiotic bacteria genomes available, it has been possible to develop evolutionary models explaining the changes undergone by these bacteria in their adaptation to the intracellular host environment. The establishment of a given symbiotic system can be a root cause of substantial changes in the partners' way of life. Furthermore, symbiont replacement and/or the establishment of bacterial consortia are two ways in which the host can exploit its interaction with environmental bacteria for endosymbiotic reinvigoration. The detailed study of diverse and complex symbiotic systems has revealed a great variety of possible final genomic products, frequently below the limit considered compatible with cellular life, and sometimes with unanticipated genomic and population characteristics, raising new questions that need to be addressed in the near future through a wider exploration of new models and empirical observations.
\end{abstract}

Keywords: endosymbiosis; genome-reduction syndrome; consortium; primary endosymbiont; secondary endosymbiont; Buchnera; Sulcia; Tremblaya; symbiotic replacement; minimal genomes

\section{Introduction}

\subsection{Brief History of Endosymbiosis and Its Importance in the Evolution of Eukaryotes}

In nature, species do not live alone but interact with others, and their interactions can have a strong impact on their evolutionary histories. Symbiosis, broadly defined as "living together" [1], is nowadays acknowledged as one of the main forces shaping life in our planet, as the evolutionary fate of the members of a steady association is mutually dependent, leading in some cases to co-cladogenesis. According to the fitness effects on the two (or more) symbiotic partners, such relationships can be referred as mutualism when both species increase their fitness, parasitism when one species increases its fitness while the fitness of the other is adversely affected, and commensalism when one partner is increasing its fitness without affecting the other one. Yet, there are no clear barriers among these possible interactions and rather we encounter a continuum that many species can transit along their life history. 
Eukaryotes from numerous clades maintain mutualistic relationships with prokaryotes, mainly bacteria [2]. Depending on the location of the symbiont with respect to the host cells, it is referred as endosymbiosis when the prokaryote symbiont lives inside a specialized eukaryote cell, called bacteriocyte, and ectosymbiosis when the symbiont lives on the host's body surface. Finally, according to the degree of dependence, the association can be obligate (or primary) and facultative (or secondary). Again, there are no clear barriers between these two categories, and facultative bacteria can become obligate under special circumstances (reviewed in [3]).

In addition to the two canonical endosymbioses that were the origin of mitochondria and chloroplasts, stable mutualistic associations have evolved frequently and independently in numerous eukaryotes groups [2]. Most of such symbioses have a biochemical basis. In the case of animals, their metabolisms are heterotrophic and many nutrients must be obtained from external sources. Thus, endosymbiotic bacteria can be used as factories for the provision of essential biomolecules that are lacking in the host diet.

Most early studies about symbiosis between bacteria and eukaryotic hosts focused on mutualistic and obligate insect-bacteria endosymbiosis. The work of scientists like the zoologist Umberto Pierantoni and the embryologist Karel Šulc at the beginning of the past century revealed that this type of relationship was widespread in many insect groups [4,5]. They recognized the bacteriome (at that time called mycetome) as an organ dedicated to keeping microorganisms inside the insect body. Inspired by these pioneering studies, Paul Buchner dedicated a good part of his scientific career to describe and decipher the meaning of the diversity of beneficial associations between insects and endosymbiotic bacteria. Among the examples presented by him in his seminal book published in English in 1965 [5], some are still being analyzed nowadays, providing new insights on this kind of intimate association, and will be the focus of this review.

\subsection{Similar Unbalanced Diets but Different Host-Symbiont Associations}

Insects represent around $85 \%$ of animal diversity, and some estimations indicate that around $15 \%$ of them maintain an endosymbiotic relationship with bacteria that, due to the strict dependence between host and symbiont, are called primary (P-) endosymbionts [6,7]. The establishment of these associations is conceived as one of the key factors of the evolutionary success and diversification of this animal group. Even though new data are accumulating, most studies concentrate on nutritional and physiological aspects (summarized in $[3,8]$ ), because one characteristic feature of most mutualistic symbiosis, as already stated by Buchner, is that the hosts feed on specialized diets lacking essential nutrients, which must be supplied by their allied bacteria [5]. The association is mutualistic because each host provides its endosymbiont(s) with a stable environment with a permanent resource provision, but it is also obligate. As a consequence, most of these bacteria cannot be cultured outside their hosts and, for this reason, should be referred to as "Candidatus" [9], although this criterion has not always been taken into account. In most cases, although the cognate insects are considered independent species, a single species name has been given to all bacteria associated with large insect clades, with each insect species presenting a given bacterial strain. For simplicity sake, along this review, the full name of the bacterial species will only be indicated the first time it appears in the text (without the "Candidatus" statement), and we will normally refer to the bacterial genus when there is only one species described.

In the genomics era, research on bacterial endosymbionts focused on the same limited number of insect lineages that had been previously used as models to define the evolutionary and molecular aspects of prokaryote-animal symbioses. Most of them belong to the order Hemiptera, the sap-sucking insects of suborders Sternorrhyncha and Auchenorrhyncha being the most widely screened. Aphids, psyllids, white flies, and mealybugs (Sternorrhyncha) feed on phloem sap that is rich in carbohydrates, but deficient in nitrogen compounds. They have established mutualistic relationships with different P-endosymbionts (Buchnera, Carsonella, Portiera, and Tremblaya, respectively), and in many cases with the help of other bacteria to meet the host's needs [7]. Among them, the symbiotic systems 
found in aphids and mealybugs will be the object of Sections 2 and 4 . Auchenorrhyncha include clades feeding on phloem (planthoppers, treehoppers, and most leafhoppers) and xylem (cicadas, spittlebugs, and primitive leafhoppers), the latter diet being the one considered ancestral [10]. Xylem is less nutritious than phloem, containing mostly minerals and inorganic compounds but being poor in organic nitrogen and carbohydrates. Most surveyed Auchenorrhyncha (both xylem- and phloem-feeding lineages) harbor Sulcia as P-endosymbiont, but it is almost always accompanied by another symbiotic partner, maintaining complex associations that were referred to by Buchner as "a fairyland of insect symbiosis" [4] that will be later unraveled (see Section 3). Other insects from different orders, also with restricted diets, have been studied, including the mammalian blood-feeding tsetse flies (Diptera) and lice (Phthiraptera), whose endosymbionts Wigglesworthia and Riesia, respectively, provide the B-complex vitamins lacking in blood, and plant feeding weevils (Coleoptera) such as Sytophilus, whose endosymbiont, Sodalis pierantonius (in honor to the pioneering work of Umberto Pierantoni), provides tyrosine for the development of the cuticle. The case of carpenter ants (Hymenoptera) and cockroaches (Blattodea) was striking because, as omnivorous animals, they feed on a complex diet but still harbor obligate endosymbiotic bacteria. The genome sequencing of their respective endosymbionts, Blochmannia and Blattabacterium, showed that their obligate dependence is related to nitrogen storage and recycling during the stages in their life cycle in which their diet cannot provide it [11,12].

Comparative genomics of the first sequenced endosymbiont genomes allowed for the determination that, during the integration process from free-living to endosymbiont, the bacteria underwent drastic genetic, phenotypic, and biochemical changes, which could be detected by comparison with free-living relatives. The changes observed are a consequence of the small effective population size undergone during the vertical transmission of the endosymbiont to the offspring, and the absence of horizontal gene transfer to compensate genetic drift [13]. Some changes, such as the accumulation of small deleterious mutations, increase in the number of non-synonymous substitutions, accelerated evolutionary rates, the loss of many regulatory functions, and the loss of mobile elements (mainly insertion sequences) are common to all long-term endosymbionts sequenced so far; others have been proven to be more lineage-specific, including an increase in high $\mathrm{A}+\mathrm{T}$ content (quite general but with some interesting exceptions that will be described later), genome stasis, and plasmid-mediated gene amplification. However, the most relevant characteristic, shared by all bacteria engaged in an intracellular lifestyle, is the genome size reduction by gene loss [2]. For this reason, this phenomenon is known as "the genome-reduction syndrome" [3].

Due to the huge amount of information accumulated during the last two decades, it would be impossible to summarize all cases in a single review. For this reason, we will focus on selected model insects harboring bacterial endosymbionts for which there is abundant literature since the very early times of the field of symbiosis, and in which different degrees of interaction with the hosts have been identified within close relatives. These examples will help us to detangle the molecular aspects of bacteria-insect symbioses from a genomics and evolutionary perspective.

\section{Aphids as the First Defined Symbiotic Model: Buchnera and Its Multiple Partners}

\subsection{Historical View of the Aphid-Buchnera Systems}

In honor of Buchner, Paul Baumann and his group gave the name of Buchnera aphidicola to the endosymbiotic bacteria (an Enterobacteriaceae within the class Gammaproteobacteria) found in the aphid Schizaphis graminum [14]. Although it was not given the status of Candidatus, it cannot be cultured outside its host, so the bacterium was defined based on its shape, localization within the aphid host, and 16S rRNA gene sequence. Since then, all the P-endosymbionts of aphids have been named B. aphidicola, even though they have coevolved with their hosts belonging to divergent aphid lineages, thus having different species names. It was the second bacterial endosymbiont of insects characterized at that time, after Blattabacterium cuenoti, endosymbiont of cockroaches [15]. Treatment with antibiotics to reduce or eliminate the bacterial endosymbionts caused abnormal growth, lack of reproduction, and premature 
death, confirming the obligate status of the endosymbiont [16]. The hosts have developed mechanisms to regulate, maintain, and transmit their symbionts; thus, as all other obligate endosymbionts, Buchnera is strictly vertically transmitted from mother to offspring. The works by Baumann and his disciples in the USA on molecular characterization of Buchnera [17] were complemented by the metabolic characterization of the aphid-bacterium system, thanks to the research performed by the team led by Angela Douglas in the UK [16], and culminated with the sequencing of the first Buchnera genome (in fact, the first sequenced endosymbiont genome) in the laboratory of Hajime Ishikawa in Japan [18].

Phylogenetic studies of aphids and their endosymbionts showed that Buchnera is a root cause of the diversification of aphids, indicating that the ancient acquisition of a Buchnera free-living ancestor (about 200 million years ago (MYA)) was followed by coevolution of host and symbiont, and the specialization of the host to different feeding niches [19]. Thus, each extant aphid species harbors a Buchnera strain suited for providing the specific nutrients that are deficient in its diet, mainly essential amino acids and some vitamins. Now that paired host/endosymbiont genomes are becoming available, it is recognized that the host is the one controlling the P-endosymbiont production of the required nutrients in a finely tuned metabolic complementation, mainly by performing some final steps in the corresponding biosynthetic pathways [20-22]. Amazingly, some of the genes involved in these functions are of bacterial origin, acquired through horizontal transfer from environmental bacteria other than the current obligate symbionts (revised in [23]). It has been proposed that the eventual acquisition of bacterial genes by the host genome is another factor contributing to the extreme genome reduction found in long-term P-endosymbionts [24,25].

The first five aphid species from which their Buchnera genomes were sequenced belong to three different subfamilies: Aphidinae (Acyrtosiphum pisum and S. graminun), Eriosomatinae (Baizongea pistacia), and Lachninae (Cinara cedri and Cinara tujafilina) [18,26-29], providing information of the genomic changes undergone by Buchnera diversifying since the origin of aphids. The comparative genomic analysis revealed an extreme case of evolutionary stasis with nearly perfect gene order conservation. However, important differences in genome size were detected, Buchnera BAp (from A. pisum) and Buchnera BCc (from C. cedri) having the largest and the smallest genomes (610 and $402 \mathrm{~kb}$ ), respectively. Their chromosomal stasis allowed for the reconstruction of the evolutionary history of losses occurring in the different lineages from the Buchnera ancestor, which should have contained at least 646 genes (the sum of all genes found in the five strains) [29]. At present, the genomes of Buchnera from 24 different aphid species have been sequenced and deposited in GeneBank, revealing that they maintain the gene order fossil, and the metabolic analysis of 18 of them is accessible through SymGenDB [30].

\subsection{From Facultative to Co-Obligate Symbionts: The Establishment of Microbial Consortia}

Occasionally, aphids harbor secondary (S-) symbionts, facultative bacteria that coexist with Buchnera. The genome sequencing of the pea aphid A. pisum showed that its immune system is compromised as it has lost the complete IMD pathway that acts against Gram-negative bacteria [20]. This could have been decisive in recognizing Buchnera as a non-pathogen (whether as a cause or a consequence of the interaction), but it also implies that other bacteria, mostly Gram-negative, can enter the insect without an effective immune barrier. In fact, all bacterial S-symbionts described in aphids up to now are Gram-negative or do not have a cell wall, as is the case of Spiroplasma [31]. They can be found in different host tissues (in their own bacteriocytes, in sheath cells, free in the haemolymph, etc.), and are normally vertically transmitted from mother to progeny, although horizontal transmission is also possible [32,33]. As they are not found in all strains nor in all individuals of a population, they are considered non-essential to the host. However, positive effects have been proven in some cases, such as rescuing the host from heat damage, providing resistance against natural enemies (as parasitoids and fungi), participating in host specialization, inducing phenotypic variation, or even causing insect color change) $[31,34,35]$. Because facultative symbiosis in Buchnera and their effects on host fitness have been the subject of several reviews in recent years, only a summary is presented here (Table 1). 
Table 1. List of Buchnera symbiotic partners that have been identified in different aphid lineages. The genomes of a few of them have been sequenced, and their characteristics are also presented. The classification of Aphididae follows [36].

\begin{tabular}{|c|c|c|c|c|c|c|c|}
\hline $\begin{array}{l}\text { Co-Symbiont: } \\
\text { Bacterium (Class) }\end{array}$ & Aphid Subfamily: Tribe & Host Examples (genus) & $\begin{array}{l}\text { Sequenced Genome } \\
\text { (Host Strain) }\end{array}$ & $\begin{array}{l}\text { Genome Size } \\
(\mathrm{Mb})\end{array}$ & GC (\%) & CDS & Refs. \\
\hline $\begin{array}{l}\text { Arsenophonus } \\
(\gamma \text {-proteobacteria) }\end{array}$ & Aphidinae: Aphidini & Aphis, Hyalopterus, Melanaphis & & & & & [37-40] \\
\hline $\begin{array}{l}\text { Acinetobacter } \\
(\gamma \text {-proteobacteria) }\end{array}$ & $\begin{array}{l}\text { Lachninae: Eulachnini * } \\
\text { Lachninae: Stomaphidini * }\end{array}$ & $\begin{array}{l}\text { Cinara } \\
\text { Stomaphis }\end{array}$ & & & & & $\begin{array}{c}411] \\
{[42,43]}\end{array}$ \\
\hline $\begin{array}{l}\text { Erdwardsiella } \\
(\gamma \text {-proteobacteria) }\end{array}$ & Lachninae: Eulachnini * & Cinara & & & & & [41] \\
\hline $\begin{array}{l}\text { Erwinia-like symbiont } \\
\text { ( } \gamma \text {-proteobacteria) }\end{array}$ & $\begin{array}{l}\text { Aphidinae: Aphidini } \\
\text { Lachninae: Eulachnini * }\end{array}$ & $\begin{array}{l}\text { Hyalopterus } \\
\text { Cinara }\end{array}$ & & & & & $\begin{array}{l}{[39]} \\
{[41]}\end{array}$ \\
\hline GLSS $(\gamma$-proteobacteria) & Lachninae: Stomaphidini * & Stomaphis & & & & & {$[44,45]$} \\
\hline $\begin{array}{l}\text { Hamiltonella defensa } \\
\text { ( } \gamma \text {-proteobacteria) }\end{array}$ & $\begin{array}{l}\text { Aphidinae: Macrosiphi } \\
\text { Aphidinae: Aphidini } \\
\text { Lachninae: Tuberolachnini * } \\
\text { Lachninae: Eulachnini * }\end{array}$ & $\begin{array}{l}\text { Acyrthosiphon, Myzus Macrosiphon, Sitobion } \\
\text { Aphis, Hyalopterus } \\
\text { Nippolachnus } \\
\text { Eulachnus, Cinara }\end{array}$ & A. pisum $5 \mathrm{AT}$ & 2.17 & 40.5 & 2,158 & $\begin{array}{c}{[40,46,47]} \\
{[39,40,48]} \\
{[42]} \\
{[41,42,44]}\end{array}$ \\
\hline $\begin{array}{l}\text { Regiella insecticola } \\
(\gamma \text {-proteobacteria) }\end{array}$ & $\begin{array}{l}\text { Aphidinae: Macrosiphini } \\
\text { Aphidinae: Aphidini } \\
\text { Lachninae: Eulachnini * }\end{array}$ & $\begin{array}{l}\text { Acyrthosiphon, Myzus Macrosiphum, Sitobion } \\
\text { Aphis } \\
\text { Cinara }\end{array}$ & A. pisum LSR1 & 2.07 & 42.5 & 1,769 & $\begin{array}{c}{[40,46,49]} \\
{[40,46,48]} \\
{[41]}\end{array}$ \\
\hline $\begin{array}{l}\text { Ricketsiella viridis } \\
(\gamma \text {-proteobacteria) }\end{array}$ & Aphidinae: Macrosiphini & Acyrthosiphon & A. pisum RA04 & 1.6 & 39 & 1,378 & {$[35,50]$} \\
\hline $\begin{array}{l}\text { Rickettsia } \\
(\alpha \text {-proteobacteria) }\end{array}$ & $\begin{array}{l}\text { Aphidinae: Macrosiphini } \\
\text { Aphidinae: Aphidini } \\
\text { Lachninae: Eulachnini * }\end{array}$ & $\begin{array}{l}\text { Acyrthosiphon, Uroleucon } \\
\text { Aphis } \\
\text { Cinara }\end{array}$ & & & & & $\begin{array}{c}{[40,48,51]} \\
{[40,48,51]} \\
{[41]}\end{array}$ \\
\hline $\begin{array}{l}\text { Serratia symbiotica } \\
(\gamma \text {-proteobacteria) }\end{array}$ & $\begin{array}{l}\text { Aphidinae: Macrosiphini } \\
\\
\text { Aphidinae: Aphidini } \\
\text { Lachninae: Lachnini * } \\
\text { Lachninae: Stomaphidini * } \\
\text { Lachninae: Tramini * } \\
\text { Lachninae: Tuberolachnini * } \\
\text { Lachninae: Eulachnini * }\end{array}$ & $\begin{array}{l}\text { Acyrthosiphon, Myzus, Macrosiphum, Sitobion, Uroleucon } \\
\text { Aphis, Rhopalosiphum, Hyalopterus } \\
\text { Pterochloroides, Lachnus } \\
\text { Stomaphis } \\
\text { Trama } \\
\text { Tuberolachnus } \\
\text { Cinara }\end{array}$ & $\begin{array}{l}\text { A. pisum TUC } \\
\text { A. fabae CWBI-2.3 } \\
\text { T. salignus STs } \\
\text { C. cedri SCc } \\
\text { C. tujafilina SCt-VCL }\end{array}$ & $\begin{array}{l}2.57 \\
3.58\end{array}$ & $\begin{array}{l}52.1 \\
52.1\end{array}$ & $\begin{array}{l}2,098 \\
3,398\end{array}$ & $\begin{array}{c}{[40,46,52,53]} \\
{[39,40,46,48,54]} \\
{[45]} \\
{[42,43]} \\
{[45]} \\
{[55]} \\
{[41,56]} \\
{[57]}\end{array}$ \\
\hline SLSS ( $\gamma$-proteobacteria) & $\begin{array}{l}\text { Lachninae: Tuberolachnini * } \\
\text { Lachninae: Eulachnini * }\end{array}$ & $\begin{array}{l}\text { Nippolachnus } \\
\text { Eulachnus, Cinara }\end{array}$ & & & & & $\begin{array}{c}{[42]} \\
{[33,41,42,45]}\end{array}$ \\
\hline
\end{tabular}


Table 1. Cont.

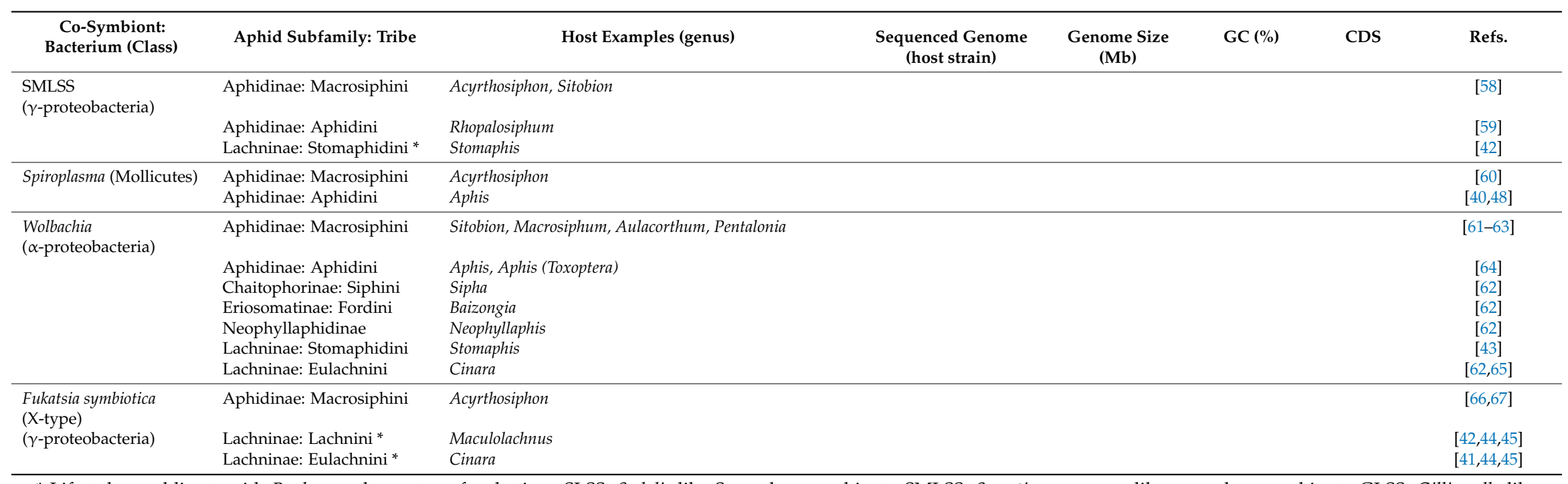

* Lifestyle co-obligate with Buchnera; the rest are facultative. SLSS: Sodalis-like Secondary symbiont. SMLSS: Serratia marcescens-like secondary symbiont. GLSS: Gilliamella-like secondary symbiont. 
The best-characterized S-symbionts have been found in A. pisum and in other members of subfamily Aphidinae [39,40]. The first S-symbionts described in the pea aphid were the gammaproteobacteria Serratia symbiotica, Regiella insecticola, and Hamiltonella defensa [68]. Since then, six additional S-symbionts have been found in aphids, five from phylum Proteobacteria, Arsenophonus, Rickettsiella, and Fukatsia symbiotica (previously known as X-type; Gammaproteobacteria) as well as Ricketssia and Wolbachia (Alphaproteobacteria), and one from phylum Firmicutes, Spiroplasma (Mollicutes) [31,39,40,62]. Of them, only Wolbachia and Arsenophonus have not been found in A. pisum so far (revised in [31]). Some S-symbiont genomes have been sequenced (Table 1), showing that they are already affected by the genome-reduction syndrome, since their genomes are smaller than those of their free-living relatives but larger than that of Buchnera. For example, the genome of S. symbiotica SAp (from A. pisum) is $2.57 \mathrm{Mb}$ in length, quite shorter than that of the free-living Serratia marcescens $(5.11 \mathrm{Mb})$. The result of their metabolic analysis is in accordance with their facultative status and helps in understanding some of the positive effects described for each association. An unexpected finding was that some facultative symbionts depend on Buchnera or another bacterium for some metabolic compounds, whose biosynthetic pathways are being pseudogenized, as is the case of S. symbiotica SAp [53].

The genome sequencing of Buchnera BCc in 2006 provided a striking result [28]. With only 362 protein coding genes, its genome represented a minimized set of genes able to support cellular life. It has conserved all the necessary genes for its own replication, transcription, and translation, as well as a simplified metabolic network to produce energy, and therefore could be considered as an autonomous cell in a particular environment [69]. However, it has partially lost its role in its symbiotic system because it is unable to synthesize tryptophan, as only the two first genes of the pathway, coding for anthranilate synthase, were present in a plasmid [70]. Prior to the publication of the Buchnera BCc genome, microscopic analyses had already shown that Buchnera BCc was not alone in the cedar aphid C. cedri [65], and it was proposed that it could be in the process of being replaced by the "healthier" coexisting S. symbiotica [28]. The sequencing of the S. symbiotica SCc genome proved that it contains the essential tryptophan genes lost in Buchnera BCc but has lost the anthranilate synthase genes preserved in Buchnera [56]. This complementation implies that anthranilate, the first metabolite in the pathway and synthesized by Buchnera, should go to S. symbiotica to be used as a precursor to synthesize tryptophan, which is then supplied to the three members of the consortium (i.e., Buchnera, Serratia, and C. cedri). This was the first described endosymbiotic consortium involving two co-obligate bacteria, Buchnera BCc and S. symbiotica SCc [56,70]. Almost at the same time, the genome of the facultative $S$. symbiotica SAp was published [53], confirming important differences in the two S. symbiotica lineages due to their obligate or facultative statuses, respectively.

The sequencing of a third S. symbiotica genome from the thuja aphid C. tujafilina, a close relative of C. cedri, provided a new surprise because $S$. symbiotica SCt was morphologically and genomically closer to SAp than to SCc $[29,57]$. The genome analysis indicated that it represents another intermediate stage in the accommodation process into the aphid-Buchnera system, and it still presents the whole tryptophan biosynthetic pathway. The sequencing of S. symbiotica STg from Tuberolagnus salignus, another member of subfamily Lachninae, revealed an even more degenerate genome $(0.65 \mathrm{Mb})$ compared with that of S. symbiotica SCc $(1.76 \mathrm{Mb})[55,56]$. A revisiting to all Buchnera genomes from Lachninae aphids indicated that the obligate consortium between Buchnera and S. symbiotica was triggered by the ancient loss of the pathway for the biosynthesis of riboflavin in an ancestral Buchnera of this subfamily [45]. Since then, S. symbiotica has undergone specific genome reduction patterns in each lineage, and phylogenetic analyses indicate that the loss of the tryptophan gene has occurred convergently in the bacterial lineages present in C. cedri and T. salignus.

A critical issue in evolutionary biology is finding traits or organisms that provide evidence of the transition from one lifestyle to another. The discovery of S. symbiotica in different stages of the accommodation to intracellular life, and their comparison with free-living relatives, offered the opportunity of comparing bacteria under three different lifestyles-free-living, facultative, and obligate endosymbionts-and allowed for the dissecting of the genomic changes undergone in the process. 
The free-living species chosen for the comparison was Serratia marcescens Db11, from Drosophila melanogaster [71]. In addition to the four above-mentioned S. symbiotica strains (three co-obligate in the Lachninae and one facultative in A. pisum), the facultative strain SAf from Aphis fabae (subfamily Aphidinae) was also sequenced. With the largest S. symbiotica genome (3.58 Mb), S. symbiotica SAf can still grow in axenic conditions [72,73]. Although each lineage may undergo convergent decay and other individually relevant processes, what is clearly observed is a gradual decrease in genome size in the different stages of the integrative symbiotic process, from free-living to co-obligate, which was accompanied by gradual changes in other genome characteristics, including the GC content (from 52.1 to $20.9 \%$ ), the number of coding genes (from 3398 to 495 ), as well as a gradual reduction in the number of copies of rRNA, tRNAs, and other non-coding RNA genes, revealing different levels of genome erosion. Other changes were not as clearly correlated with genome reduction but provided new clues on the intermediate stages of the process, which can be specific to the evolutionary momentum of each lineage. Thus, there is great enrichment of pseudogenes in the two facultative and two co-obligate strains, whereas the small S. symbiotica STs genome is almost deprived of them. Additionally, like other large endosymbiotic genomes, S. symbiotica SAf, SAp, and SCt display a great enrichment of mobile elements in comparison with the free-living counterpart, whereas in the smaller genomes of S. symbiotica SCc and SCt, there are no even traces of such elements, in congruence with similar-sized endosymbiotic genomes [74]. The increase in mobile elements in recently acquired facultative endosymbionts, with a great potential as recombination sites, and their progressive loss leading to their complete disappearance in obligate endosymbionts are implied in the abundance of chromosomal rearrangements detected between free-living and facultative symbiont genomes, opposite to the chromosomal stasis in long-term P-endosymbionts [75].

\subsection{Replacement of Symbionts}

The genome-reduction syndrome undergone by obligate endosymbionts may end compromising their corresponding symbiotic functions by the loss or pseudogenization of genes that are necessary for the association, unless the host or another symbiont can compensate for such functional losses [8]. As stated above, one solution is the establishment of an obligate symbiotic consortium, when the coexistence of both bacteria maintains a "healthy" system by establishing metabolic complementation. Another possibility is the replacement of the inefficient P-endosymbiont by a new intracellular bacterium that has not yet started losing essential functions, and can even be a source of novel metabolic capabilities to the host. However, despite the amount of partners that can coexist with Buchnera-either facultative or co-obligate-and its reduced genome, only two cases of Buchnera replacement have been documented up to now. Members of the Asian tribe Ceratiphidini (subfamily Ceratiphinae) lack Buchnera, which has been replaced by a yeast-like symbiont (YLS) [76]. The functional and evolutionary analysis of this eukaryotic symbiont revealed that it is vertically transmitted, has a broader metabolic repertoire than Buchnera, and thus can fulfill nutritional host needs [77]. The second case has been found very recently in members of genus Geopemphigus (Erisosmatinae: Fordini) [78], where Buchnera has been replaced by Skilesia alterna, a maternally transmitted bacterial symbiont from the phylum Bacteroidetes. As in the previous case, this new endosymbiont has retained biosynthetic pathways for essential amino acids and vitamins. Moreover, its $1.32 \mathrm{Mb}$ genome and its $37.0 \%$ GC content indicates that the degenerative genome syndrome is underway.

The subfamily Lachninae is particular among aphids, not only because all its members seem to have established co-obligate associations with Buchnera but also because multiple replacements of the co-obligate symbiont have been documented [33,41,44,45,79-81]. As stated previously, in this subfamily, Buchnera holds highly reduced genomes and, probably because of the loss of the riboflavin pathway in the ancestor of the lineage, members of this subfamily depend on a second co-obligate endosymbiont to complement Buchnera functions $[41,45,53,55,57]$. So far, the analysis for the presence of endosymbiont bacteria in species representative of five tribes of this subfamily (Lachnini, Stomaphidini, Tramini, Tuberolachnini, and Eulachnini) indicates that, while most species host S. symbiotica, some are 
associated with other members of Enterobacteriaceae (summarized in [45]). Fukatsia symbiotica was found in some Lachnini and Eulachnini species; Serratia marcescens-like secondary symbiont (SMLSS), Arsenophonus, Gilliamella-like secondary endosymbiont (GLSS), and Erwinia-like bacteria in species belonging to Stomaphidini; Sodalis-like secondary symbiont (SLSS) and Hamiltonella in some species of Tuberolachnini and Eulachnini; and Wolbachia in Stomaphidini and Eulachini. The most parsimonious scenario to explain all these data is that a second endosymbiont, probably S. symbiotica, was established early in the ancestor of subfamily Lachninae, followed by at least six independent events of symbiotic replacements and, eventually, the recruitment of a third endosymbiont.

Cinara (Eulachnini) is the most diverse genus of the subfamily, and it has been broadly studied for the characterization and phylogenetic analysis of the resident symbiont accompanying Buchnera [41]. A recent study by Meseguer and coworkers supports the previous hypothesis of S. symbiotica present in the common ancestor of the genus, followed by its diversification and replacements in different clades, in eight cases by another Serratia. All the Enterobacteriaceae species detected previously, plus Rickettsia, Regiella, Edwardsiella, Acinetobacter, and an unnamed member of this family, were detected in at least one species. The authors did not find any association between the acquisition of a new symbiotic partner and the ecological expansion of the corresponding aphid hosts. For this reason, they proposed that the symbiotic succession would be driven by factors such as genome deterioration or competition between bacteria with similar metabolic capabilities. Morphology of the co-resident bacteria has been studied by FISH in some species, revealing a wide variety of cell shapes and tissue tropism for the same bacterial genus in different insect hosts. Shifts in tissue tropism could cause bacteriocyte arrangements within the bacteriome and stable internalization of the second symbiont in distinct bacteriocytes [45]. Once this happens, there is probably no turning back and the genome reduction accelerates until a genome similar to that found in S. symbiotica from T. salignus is generated [55].

\section{The Case of Cicadas and Relatives: Sulcia and Its Multiple Partners}

\subsection{Consortia and Replacements in the Auchenorrhyncha}

A second large group of sap-sucking insects of the order Hemiptera, extensively studied for the presence of P-endosymbionts, is the Auchenorrhyncha (Figure 1; Table 2). This suborder is composed of four superfamilies grouped in two main lineages: Cicadoidea (cicadas), Cercopoidea (spittlebugs), Membracoidea (leafhoppers and treehoppers), grouped in the cicadomorph clade, and Fulgoroidea (planthoppers). Xylem-feeding appears to be an ancestral character of all three modern cicadomorph lineages and has been retained in cicadas, spittlebugs, and a few primitive leafhoppers [10]. Buchner, and specially his student H. J. Müller, extensively studied this group of insects [82]. Their microscopic survey of hundreds of species allowed for the observation that most of them contain more than one symbiont, although they all shared a common one that was called at that time "a-symbiont." Müller's hypothesis was that the ancestor of the a-symbiont infected the ancestor of the Auchenorrhyncha before the split of the two main clades. He also proposed that the a-symbiont was joined, and sometimes replaced, by one or more additional symbiont types in different descendant host lineages, resulting in the current variety of associations. These hypotheses still hold based on metagenomic studies. This is now considered a perfect example of how the establishment of a symbiotic bacterial consortium can be at the origin of great evolutionary changes in the host's lifestyle, while the genome degeneration of the consortium partners may end in the extinction and replacement of the more deteriorated and inefficient one, which is similar to what has also been described in aphids.

Müller's a-symbiont was characterized by phylogenetic and FISH analyses in 2005 as a Bacteroidetes [83] and was given the name of Sulcia muelleri, the species name in his honor and the genus Sulcia after the pioneer symbiologist Karel Šulc. Its phylogenetic congruence with that of the corresponding hosts indicates that modern Sulcia are descendants of an ancient symbiont that was acquired by the ancestor of all Auchenorrhyncha members, at least 260 MYA. Soon after the description of this new endosymbiotic species, akin to what was found in C. cedri and almost at the same time, 
the gammaproteobacterium Baumannia cicadellinicola was discovered as a co-obligate endosymbiont with Sulcia in the leafhopper Homalodisca vitripennis [84]. However, that was just the beginning. Later on, the availability of genomes of many different Sulcia strains, as well as genomes of their variable partners in different xylem and phloem-feeding clades, revealed an endless story of alliances and replacements in the evolutionary history of Sulcia and its symbiotic fellows. We present only the tip of the iceberg of these complicated "family matters" (Figure 1).

Table 2. Genomes of P-endosymbionts of Auchenorrhyncha that have been completely sequenced to date. The host species are ordered as in Figure 1.

\begin{tabular}{|c|c|c|c|c|c|}
\hline Insect host & P-endosymbiont & Genome size (kb) & GC (\%) & CDS & Ref. \\
\hline Mogannia minuta & Sulcia SMMOGMIN & 243,55 & 22.30 & 220 & [85] \\
\hline \multirow[t]{2}{*}{ Vagitanus terminalis } & Sulcia SMVAGTER & 245,30 & 22.70 & 227 & [86] \\
\hline & Hodgkinia HCVAGTER & 353 & 30.0 & nd & \\
\hline \multirow[t]{2}{*}{ Magicicada tredecim } & Sulcia SMMAGTRE & 268,54 & 22.70 & 224 & [85] \\
\hline & Hodgkinia HCMAGTRE & 1571 & 29.1 & 252 & \\
\hline \multirow[t]{2}{*}{ Muda kuroiwae } & Sulcia SMMUDKUR & 266,95 & 22.60 & 248 & [85] \\
\hline & Hodgkinia HCMUDKUR & 909 & 27.1 & nd & \\
\hline \multirow[t]{2}{*}{ Kosemia yezoensis } & Sulcia SMKOSYEZ & 244,20 & 22.80 & 221 & [85] \\
\hline & Hodgkinia HCKOSYEZ & 1863 & 30.0 & nd & \\
\hline Graptopsaltria bimaculata & Sulcia SMGRABIM & 271,62 & 22.60 & 253 & [85] \\
\hline Graptopsaltria nigrofuscata & Sulcia SMGRANIG & 271,57 & 22.60 & 253 & [85] \\
\hline Hyalessa maculaticollis & Sulcia SMHYAMAC & 272,58 & 22.50 & 249 & [85] \\
\hline Euterpnosia chibensis & Sulcia SMEUTCHI & 273,71 & 22.60 & 257 & [85] \\
\hline Tanna japonensis & Sulcia SMTANJAP & 278,30 & 22.50 & 256 & [85] \\
\hline Meimuna iwasakii & Sulcia SMMEIIWA & 272,32 & 22.60 & 253 & [85] \\
\hline Meimuna kuroiwae & Sulcia SMMEIKUR & 271,07 & 22.60 & 253 & [85] \\
\hline Meimuna opalifera & Sulcia SMMEIOPA & 271,56 & 22.60 & 252 & [85] \\
\hline Meimuna oshimensis & Sulcia SMMEIOSH & 270,60 & 22.60 & 253 & [85] \\
\hline Terpnosia nigricosta & Sulcia SMTERNIG & 273,63 & 22.70 & 256 & [85] \\
\hline Terpnosia vacua & Sulcia SMTERVAC & 273,80 & 22.60 & 256 & [85] \\
\hline \multirow{2}{*}{ Diceroprocta semicincta } & Sulcia SMDSEM & 276,98 & 22.60 & 242 & [85] \\
\hline & Hodgkinia Dsem & 144 & 58.4 & 169 & \\
\hline \multirow[t]{2}{*}{ Platypleura kaempferi } & Sulcia SMPLAKAE & 268,04 & 22.50 & 248 & [85] \\
\hline & Hodgkinia HCPLAKAE & 349 & 47.9 & nd & \\
\hline \multirow[t]{2}{*}{ Auritibicen bihamatus } & Sulcia SMAURBIH & 276,77 & 22.80 & 256 & [85] \\
\hline & Hodgkinia HCAURBIH & 474 & 45.0 & nd & \\
\hline \multirow[t]{2}{*}{ Auritibicen japonicus } & Sulcia SMAURJAP & 278,18 & 22.80 & 259 & [85] \\
\hline & Hodgkinia HCAURJAP & 438 & 45.8 & nd & \\
\hline Cryptotympana atrata & Sulcia SMCRYATR & 273,23 & 22.70 & 252 & [85] \\
\hline Cryptotympana facialis & Sulcia SMCRYFAC & 270,78 & 22.70 & 238 & [85] \\
\hline Chonosia crassipennis & Hodgkinia CHOCRA & 149 & 38.7 & 170 & [87] \\
\hline \multirow[t]{5}{*}{ Tettigades limbata } & Hodgkinia TETLIM1 & 145 & 45.4 & 130 & [87] \\
\hline & TETLIM2 & 131 & 45.1 & 73 & \\
\hline & TETLIM3 & 128 & 47.8 & 50 & \\
\hline & TETLIM4 & 126 & 47.2 & 47 & \\
\hline & TETLIM5 & 122 & 45.8 & 39 & \\
\hline Tettigades auropilosa & Hodgkinia TETAUR & 126 & 46.3 & 117 & [87] \\
\hline
\end{tabular}


Table 2. Cont.

\begin{tabular}{|c|c|c|c|c|c|}
\hline Insect host & P-endosymbiont & Genome size (kb) & GC (\%) & CDS & Ref. \\
\hline \multirow[t]{4}{*}{ Tettigades chilensis } & Hodgkinia TETCHI1a & 130 & 44.9 & 163 & [87] \\
\hline & TETCHI1b & 129 & 44.8 & 156 & \\
\hline & TETCHI2 & 117 & 45.8 & 115 & \\
\hline & TETCHI4 & 106 & 45.6 & 114 & \\
\hline Tettigades ulnaria & Hodgkinia TETULN & 150 & 46.4 & 170 & [87] \\
\hline \multirow[t]{3}{*}{ Tettigades undata } & Sulcia TETUND & 270,03 & 23.00 & 247 & {$[88]$} \\
\hline & Hodgkinia TETUND1 & 134 & 46.8 & 121 & \\
\hline & TETUND2 & 141 & 46.2 & 140 & \\
\hline \multirow[t]{3}{*}{ Tettigades undata } & Hodgkinia TETLON1 & 133 & 47.7 & 104 & [87] \\
\hline & TETLON2a & 140 & 46.5 & 128 & \\
\hline & TETLON2b & 137 & 46.7 & 109 & \\
\hline Philaenus spumarius & Sulcia PSPU & 285,35 & 20.90 & 257 & [89] \\
\hline \multirow[t]{2}{*}{ Clastoptera arizonana } & Sulcia CARI & 276,51 & 21.10 & 246 & [90] \\
\hline & Zinderia & 209 & 13.5 & 206 & \\
\hline \multirow[t]{2}{*}{ Draeculacephala minerva } & Sulcia DMIN & 243,93 & 22.50 & 226 & [91] \\
\hline & Baumannia & $636+3.5$ & 31.6 & $517+5$ & \\
\hline \multirow{2}{*}{ Graphocephala atropunctata } & Sulcia BGSS & 244,62 & 22.50 & 227 & [92] \\
\hline & Baumannia & 759 & 39 & 669 & \\
\hline \multirow{2}{*}{ Homalodisca vitripennis } & Sulcia GWSS & 245,53 & 22.40 & 227 & [84] \\
\hline & Baumannia & 686 & 33.2 & 595 & \\
\hline Nephotettix cincticeps & Sulcia NC & 192,24 & 23.70 & 176 & $\mathrm{U}$ \\
\hline Dalbulus maidis & Sulcia ML & 190,41 & 24.10 & 187 & [93] \\
\hline \multirow[t]{2}{*}{ Macrosteles quadrilineatus } & Sulcia ALF & 190,73 & 24.00 & 188 & [94] \\
\hline & Nasuia & 112 & 17.1 & 138 & \\
\hline \multirow{2}{*}{$\begin{array}{l}\text { Macrosteles } \\
\text { quadripunctulatus }\end{array}$} & Sulcia PUNC & 190,66 & 24.00 & 181 & [95] \\
\hline & Nasuia & 112 & 16,6 & 138 & \\
\hline \multirow[t]{2}{*}{ Entylia carinata } & Sulcia ENCA & 218,03 & 23.00 & 198 & [96] \\
\hline & Nasuia & 144.6 & 15.2 & 159 & \\
\hline \multirow[t]{3}{*}{ Oliarus filicicola } & Sulcia OLIH & 156,58 & 24.90 & 152 & [97] \\
\hline & Vidania & 136 & 18.2 & 154 & \\
\hline & Purcelluella & 480 & 21.2 & 431 & \\
\hline
\end{tabular}

U: Unpublished; nd: no determined.

At this time, up to 34 complete Sulcia genomes are available in GenBank, and in some cases their symbiotic partners have also been sequenced (Table 2). The analyzed Sulcia genomes have many features in common with what was found in Buchnera. An important difference is that, while Buchnera is the only P-endosymbiont in many aphid lineages, Sulcia has almost always been detected along with, and complemented by, one or more co-primary microorganisms. The Sulcia genomes are collinear $[87,90]$, and the differences in their gene content imply a perfect metabolic complementation with the additional co-existing endosymbionts to provide their host with essential biomolecules lacking in their nutritionally deficient diet. Very often this involves the partial implementation of a given pathway in each of the partners. The ancestral Sulcia had an already streamlined genome, as deduced from the very small sizes of the extant Sulcia genomes that have been sequenced (from 157 to $285 \mathrm{~kb}$ ).

Three betaproteobacterial species have been identified co-occurring with Sulcia: Nasuia deltocephalinicola in phloem-feeding leafhoppers of subfamily Deltocephalinae (family Cicadellidae) from whom it received the species name [98] but also of family Membracidae [96], Zinderia insecticola in many spittlebugs (Cercopoidea) [90], and Vidania fulgoroideae in planthoppers (Fulgoroidea) [99]. Zinderia and Nasuia (collectively named BetaSymb clade) are very closely related [94], which indicates that a common ancestor infected the lineage leading to Cicadomorpha early after the establishment of the endosymbiosis with Sulcia. Vidania appears to be a descendant of the ancient symbiont that infected the common ancestor of superfamily Fulgoroidea at least 130 MYA [82]. The genome reduction syndrome has been dramatic and 
these symbiotic relationships lead to some of the most highly reduced genomes sequenced to date (down to $112 \mathrm{~kb}$ for Nasuia ALF and PUNC, found in two leafhoppers of genus Macrosteles) [94,95]. These tiny genomes are below the minimal genome status because they have lost genes needed for the maintenance of a living cell (including DNA replication, transcription, and translation) [69,100]; therefore, even these essential functions must be performed in cooperation and shared by the joined symbiotic partners.

While Sulcia-like Buchnera—is rarely lost, the Beta-endosymbionts have been secondarily lost many times and, akin to what has been described in Lachninae aphids, in most cases they have been replaced by different "healthier" partners [8]; in other cases, a third partner joined the consortium to cope with the extreme genome degeneration of the two oldest co-primary endosymbionts (Figure 1). Thus, in the BetaSymb clade, Zinderia has been replaced by the alphaproteobacterium Hodgkinia cicadicola in cicadas (Cicadoidea) [94], and Nasuia has been replaced by Baumannia in subfamily Cicadellinae $[84,91,92,101]$ and, although it has been retained in most analyzed members of the sister subfamily Deltocephalinae, it seems to have been lost in the corn leafhopper, Dalbulus maidis $[93,102]$. In the Fulgoroidea, Vidania and Sulcia have been found together with the gammaproteobacterium Purcelliella pentastirinorum in several planthoppers of family Cixiidae $[82,97,99,103]$.

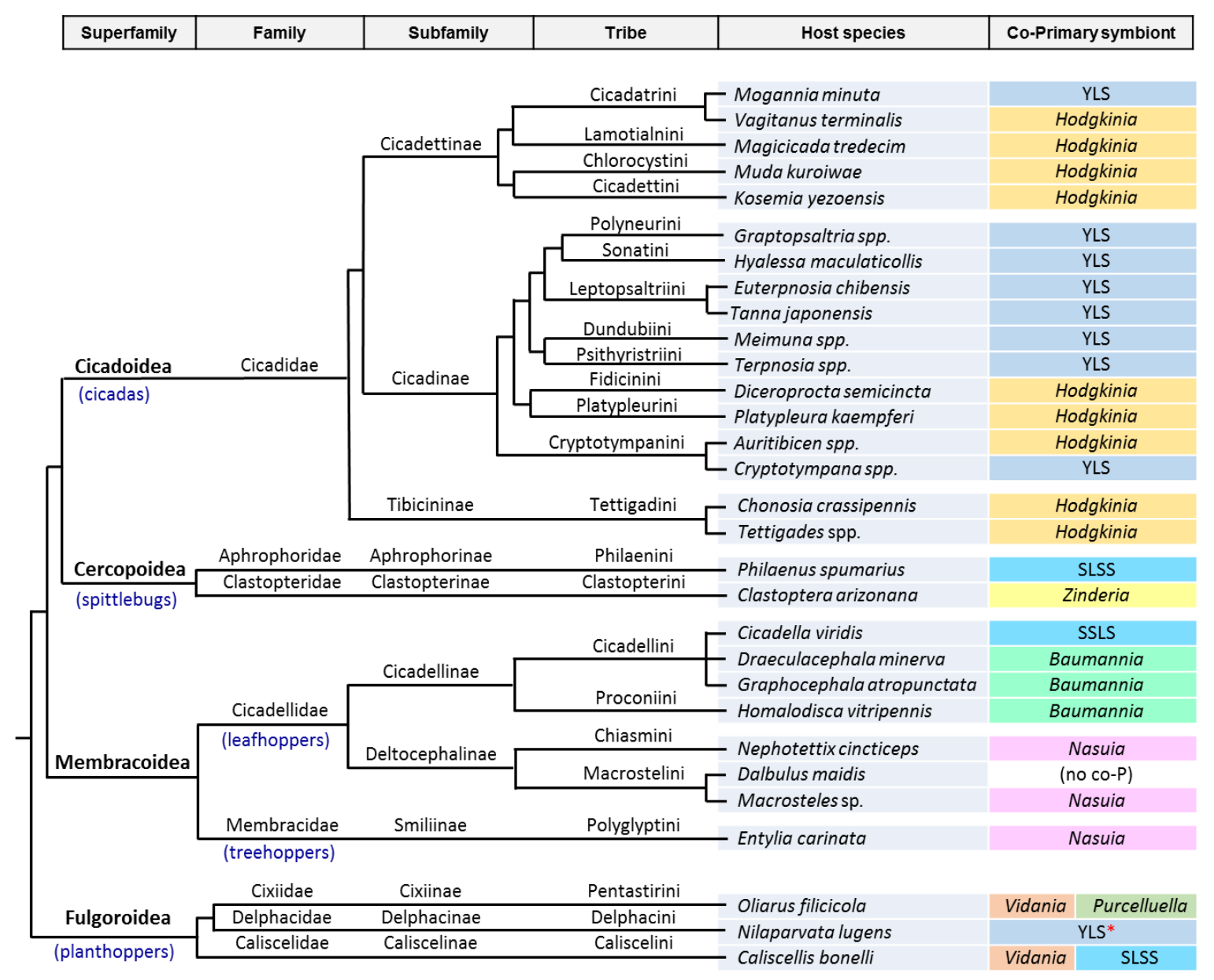

Figure 1. Schematic summary of the different clades of Auchenorrhyncha mentioned in the text and their corresponding co-primary endosymbionts that have been found in addition to Sulcia (except in the case labeled with an asterisk, where the YLS is replacing Sulcia). The evolutionary relationship of the clades is based on [104-106].

In many cases, the new allied endosymbiont has been recruited from the same clades that have been repeatedly found as pathogens or facultative symbionts in other sap-feeding insects, suggesting that they can be an environmental source for symbiont exchange and evolutionary reinvigoration 
when the P-endosymbiont cannot cope with its symbiotic function. As mentioned before, in aphids there are cases in which intracellular symbiotic yeasts have replaced Buchnera. Similarly, there are many cases in which YLS phylogenetically related to the entomopathogenic genus Ophiocordyceps (Ascomycota: Sordariomycetes: Hypocreales) have joined or replaced Sulcia and/or its bacterial partner. Thus, Sulcia has been replaced in some young lineages of Delphacidae planthoppers (Fulgoroidea) [107]; neither Vidania nor Sulcia were found in some young lineages of family Delphacidae where a vertically transmitted YLS was found [107,108]; and the same kind of YLS was found in some leafhoppers of subfamilies Deltocephalinae [109-111] and Ledrinae [112], whether replacing Nasuia or in an intermediate stage in which both Nasuia and the YLS coexist with Sulcia. In addition, many independent cases of Hodgkinia replacement have been found in several tribes of two cicadidae subfamilies; in fact, it is possible that repeated Hodgkinia-fungus and fungus-fungus replacements had occurred [85]. Located in the fat body of the insects, these YLS play an essential role in uric acid recycling [107,113]. It is worth mentioning that, in the cases of Buchnera replacement in aphids, the YLS serves a different endosymbiotic purpose [77]. As for common environmental and facultative symbiotic bacteria, several Sodalis-like symbionts have participated in replacements or tripartite associations in the Auchenorrhyncha. For example, in superfamily Cercopoidea, a replacement of Zinderia by a Sodalis-like symbiont or intermediate tripartite consortia have been described in spittlebugs of the tribe Philaenini [89,114]. In superfamily Fulgoroidea, a Sodalis-like symbiont has joined the association between Sulcia and Vidania in Caliscelis bonelli (Caliscelidae) [115]. In all the above-mentioned associations, each endosymbiont lives in its own bacteriocytes, and, in some cases, additional putative facultative symbionts have been also found [107,116-118].

Among all the diversity of endosymbiotic systems found in Auchenorrhyncha, the most widely studied correspond to cicadas, since it is in this superfamily that the most bizarre endosymbiont genomes have been found. For this reason, they deserve their own subsection in this review.

\subsection{The Peculiarities of the Hodgkinia Genomes and Its Coexisting Interdependent Lineages within a Single Host}

The genomes of different Hodgkinia strains have been sequenced, and every new genome analyzed provided new surprises. The first genome, from the P-endosymbiont of the glassy-winged sharpshooter Diceroprocta semicincta [119], had a GC base composition of $58.4 \%$, very different from all other endosymbiont genomes sequenced at that time. Most strikingly, the genome annotation revealed that the UGA stop codon was reassigned to tryptophan in this bacterium. The same codon reassignment was later detected in the tiny genomes of Zinderia and Nasuia $[90,94]$, even though they were AT-rich, ruling out the hypothesis that base composition is a root cause of codon reassignment. It is worth mentioning that the same genetic-code modification had been previously described in the reduced and AT-rich genomes of mycoplasmas [120] and some mitochondrial lineages [121], representing a remarkable example of evolutionary convergence. It has been proposed that this reassignment was triggered by the loss of release factor RF2 (encoded by prfB), whose function is to recognize this stop codon [119].

Nevertheless, what makes Hodgkinia strains extraordinary is their capability to present alternative interdependent lineages, with different genotypes and genome rearrangements, inside a given host. The coexistence of two cytologically distinct but metabolically interdependent Hodgkinia clades, with reciprocal patterns of gene loss and retention, was first detected in some cicadas of genus Tettigades [88]. Soon later, an impressive level of genome complexity was described in the longest-lived cicadas of genus Magicicada [86,122]. In each Magicicada species, the Hodgkinia genome is composed by many subgenomic circles of different size, with an extremely reduced gene density. Additionally, the same gene can be present in different circles, and not all circles are present in all Hogkinia cells within a single host. Similarly to other highly reduced endosymbiont genomes, and contrary to the first Hodgkinia genomes sequenced, most of these complex Hodgkinia genomes have a low GC content (e.g., among the 39 sequenced subgenomic circles of the Hodgkinia found in M. neotredecim, the GC content ranges from 21.9 to 42.4 , with only three circles having a GC content above 35\% [122]), an indication that a high GC 
content is not a general trait of this species. Remarkably, genome instability and expansion because of the increase of "junk DNA," leading to the existence of subgenomic molecules with low coding capacity, are common in mitochondrial lineages from some plants, another example of evolutionary convergence. More recently, an astonishing level of complexity was detected when 19 different Hodgkinia genomes, isolated from only five specimens from diverse Chilean populations of Tettigades spp., were sequenced [87]. The results suggest that a single ancestral Hodgkinia lineage has split at least six independent times in this insect genus over the last 4 million years. Two to six Hodgkinia lineages can be found in each single host, and each lineage presents different genomes formed by subgenomic molecules. Each lineage genome contains a different set of genes and, most of the time, does not contain all genes needed for the symbiotic relationship nor the provision of essential informational bacterial functions (i.e., DNA replication, transcription, and translation). Therefore, these different lineages coexisting in a single host rely on each other to survive. Furthermore, different combinations of Hodgkinia lineages can be found in each host. The degenerative process leading to this amazing splitting phenomenon is progressive and has no way back, since it will be impossible to recover the genomic information that has been lost. The extreme degeneration of these genomes appears to indicate that this endosymbiont has reached a critical stage in genome erosion and could be close to collapse, which could be the cause of the large number and variety of replacements found in this superfamily of insects.

\section{The Case of Mealybugs: Not a “Simple" Matryoshka Doll}

\subsection{A Surprising Nested Endosymbiotic System}

Another kind of exceptional consortium was found in most mealybugs (Hemiptera: Sternorrhyncha: Pseudoccidae) of subfamily Pseudococcinae. Early symbiologists, including Buchner, explained that this symbiotic system was formed by bacteria embedded within mucous spherules [123]. By microscopic and molecular studies on the citrus mealybug Planococcus citri, von Dohlen and coworkers discovered that such vesicles were, in fact, a nested endosymbiotic system [124]. In these insects, the betaproteobacterium Tremblaya princeps harbors a gammaproteobacterium inside. No nested endosymbiotic consortia have been described outside this mealybugs' subfamily up to now.

The inner gammaproteobacteria were initially considered as S-symbionts because they are polyphyletic [123]. However, genomic studies performed on several Pseudococcinae mealybugs revealed that they are co-primary, based on the intricate interdependence between both symbionts, involving not only metabolic but also informational functions. Several nested endosymbiotic consortia have been sequenced [125-129], revealing many commonalities among them that must also be considered quite unusual for obligate endosymbionts, although some of them are also shared with some Hodgkinia strains. Thus, the comparison among several T. princeps strains revealed a highly conserved genome architecture, as in other long-established P-endosymbionts [128], but they all have a GC-content higher than expected for a P-endosymbiont. Although all sequenced strains possess tiny genomes (137-144 kb), they have a reduced coding density and present repeated sequences evolving under concerted evolution, including a partial genomic duplication of the ribosomal operon and neighbor genes [130]. In fact, even though ribosomal genes and genes involved in the biosynthesis of essential amino acids constitute most of its genome, T. princeps depends on its inner partner to make up both ribosomes and essential amino acids $[125,126]$.

While patchwork complementation for amino acid biosynthesis is a common feature of many endosymbiotic consortia (Figure 2), this was the first described case in which all energy sources must be provided by one of the symbiotic allies, similar to mitochondria in the eukaryotic cell. The preservation of two genes coding for channels associated with osmotic stress response (mscL and $y b a \mathrm{~L}$ ) in the T. princeps genome was also surprising, because they have not been identified in other long-term P-endosymbionts. It was proposed that they might reflect a special requirement of nested endosymbiosis, and be involved in the exchange of molecules between both partners [127]. As for the 
inner gamma-endosymbiont, the maintenance of an almost-complete DNA recombination machinery, unusual among long-established endosymbionts, has been proposed to be involved in the concerted evolution of the duplicated loci in T. princeps [131].



Figure 2. Diverse solutions implemented by different symbiotic systems for the biosynthesis of tryptophan from D-erythrose-4-phosphate, showing the complementation achieved in different consortia. Notice that T. phenacola PPER corresponds to a single chimeric genome.

Similarly to what was found in the other model consortia described in this review, different mealybug lineages have gone through a complex evolutionary history of independent acquisitions and replacements of different nested gamma-endosymbionts [128,129,132]. This is an indication that, even in this highly integrated symbiotic consortia, extensive symbiont turnover is possible, and maybe essential, for evolutionary reactivation of extremely degenerate genomes. Most of these newly acquired inner bacteria belong, once more, to the Sodalis-like clade, although they do not form a monophyletic group. 


\subsection{The Fist Chimeric Endosymbiont}

Mealybugs are classified in subfamilies Pseudococcinae (the one described above) and Phenacoccinae. Based on phylogenetic studies, the betaproteobacterial ancestor of genus Tremblaya infected the mealybug ancestor before the split of both subfamilies [133]. As seen above, T. princeps evolving in most Pseudococcinae lineages were later on infected multiple times by different gammaproteobacteria. This was not the case of the sister species Tremblaya phenacola in the Phenacoccinae, which has always been described alone or has been replaced by different Bacteroidetes in some clades [22,134]. In coherence with this view of the need of a single P-endosymbiont in this subfamily, the highly reduced genome of T. phenacola PAVE, from Phenacoccus avenae, presented all genes needed to fulfill all essential endosymbiotic functions attributed to the beta-gamma consortia found in Pseudococcinae mealybugs [22]. Surprisingly, when the genome of the endosymbiont from the close relative Phenacoccus peruvianus was sequenced, it was found that nearly half of the genome contained sequences taxonomically affiliated to Gammaproteobacteria [135], even though the bacterium was named T. phenacola PPER based on its 16S rRNA gene [132]. Additionally, the genome could not be fully assembled, even using Nanopore sequencing (which allows for the sequencing of long DNA molecules, up to several hundred $\mathrm{kb}$ ). In fact, the results obtained indicated the coexistence of different genome organizations, none of which corresponded to a full genome, favored by the presence of many repeated sequences. Although the possibility of lineage splitting has not been analyzed in this insect, its similarity to the case of Hodgkinia points to that. It seems that, at least in the lineage leading to T. phenacola PPER, a gammaproteobacterium entered the symbiotic association. The establishment of a nested consortium, similar to that found in the Pseudococcinae, cannot be discarded prior to the genomic fusion of the two co-occurring endosymbionts. The presence of a recombination machinery in the newly acquired gamma-endosymbiont must have triggered the loss of redundant genes, as well as the observed gene shuffling, leading to a genome in which a single copy of each gene has been preserved [135]. Once more, the phenomenon resembles what has been found in mitochondria, where cases of genome fusion and rearrangements caused by homologous recombination events have been described [136,137].

\section{Concluding Remarks and Future Perspectives in the Field}

In this review we have presented paradigmatic examples of endosymbiotic systems, from the very beginning of the intimate association to the most extreme cases of genome reduction, including the ultimate fate of the endosymbionts once they reach a limit stage of degeneration in which they cannot fulfill the host needs. We have described the transformations undergone by a free-living bacterium on becoming an intracellular endosymbiont. We know now that, despite the huge variability of systems found in nature to date, convergent solutions are achieved in most cases (e.g., for the joined biosynthesis of amino acids and vitamins in patchwork pathways; Figure 2). Furthermore, bacterial and fungal species from some widely distributed clades living in sympatry with the insect hosts can enter the symbiotic association, and can be used as copartners or even replace the first obligate endosymbiont. This explains that, for example, some Sodalis-like bacteria are found in a huge number of associations with species from all three model insect lineages cited in this review.

The complete knowledge of a symbiotic system requires a system biology approach in which, in addition to in silico predictions based on genomic analyses and phylogenetic information, transcriptomic, proteomic, and metabolomic analyses are also needed. Some studies using these new approaches have been already performed [21,22,138-141]. For sure, further studies will come in the near future, allowing for the dissection of insect-endosymbiont interactions to disentangle the convergent solutions achieved in the different systems for host/endosymbiont(s) metabolic complementarity and collaboration.

From an applied point of view, the integration of all knowledge about these symbiotic systems will allow for the determination of the best conditions for laboratory culture of intracellular bacteria with reduced genomes. It will then be possible to design experimental approaches in which the bacteria can be manipulated and, through the elimination of non-essential genes, resulting in a simplified 
natural cell. There are other approaches of broad interest in synthetic biology, such as the possibility to generate an adequate chassis in which genetic modules are added for the performance of a function of interest, and the always ambitious goal of, using all this information, designing new semisynthetic cells with minimized genomes that support life with alternative minimal metabolisms.

Funding: This research was funded by European Regional Development Fund (ERDF) and Ministerio de Economía y Competitividad (Spain), grant number BFU2015-64322-C2-1-R; Conselleria d'Educació, Generalitat Valenciana (Spain), grant number PROMETEO/2018/133.

Conflicts of Interest: The authors declare no conflict of interest.

\section{References}

1. Martin, B.D.; Schwab, E. Current usage of symbiosis and associated terminology. Int. J. Biol. $2012,5$. [CrossRef]

2. Moya, A.; Pereto, J.; Gil, R.; Latorre, A. Learning how to live together: genomic insights into prokaryote-animal symbioses. Nat. Rev. Genet. 2008, 9, 218-229. [CrossRef] [PubMed]

3. Latorre, A.; Manzano-Marín, A. Dissecting genome reduction and trait loss in insect endosymbionts. Ann. N. Y. Acad. Sci. 2017, 1389, 52-75. [CrossRef] [PubMed]

4. Sapp, J. Paul Buchner (1886-1978) and hereditary symbiosis in insects. Int. Microbiol. 2002, 5, 145-150. [CrossRef] [PubMed]

5. Buchner, P. Endosymbiosis of Animals with Plant Microorganisms; Interscience Publishers: New York, NY, USA, 1965; p. 909.

6. Douglas, A.E. Mycetocyte symbiosis in insects. Biol. Rev. Camb. Philos. Soc. 1989, 64, 409-434. [CrossRef] [PubMed]

7. Baumann, P. Biology bacteriocyte-associated endosymbionts of plant sap-sucking insects. Annu. Rev. Microbiol. 2005, 59, 155-189. [CrossRef] [PubMed]

8. Sudakaran, S.; Kost, C.; Kaltenpoth, M. Symbiont acquisition and replacement as a source of ecological innovation. Trends Microbiol. 2017, 25, 375-390. [CrossRef] [PubMed]

9. Murray, R.G.E.; Stackebrandt, E. Taxonomic note: Implementation of the provisional status Candidatus for incompletely described procaryotes. Int. J. Syst. Bacteriol. 1995, 45, 186-187. [CrossRef] [PubMed]

10. Shcherbakov, D. The 270 million year history of Auchenorrhyncha (Homoptera). Denisia 2002, 176, 29-36.

11. Gil, R.; Silva, F.J.; Zientz, E.; Delmotte, F.; Gonzalez-Candelas, F.; Latorre, A.; Rausell, C.; Kamerbeek, J.; Gadau, J.; Holldobler, B.; et al. The genome sequence of Blochmannia floridanus: comparative analysis of reduced genomes. Proc. Natl. Acad. Sci. USA 2003, 100, 9388-9393. [CrossRef] [PubMed]

12. López-Sanchez, M.J.; Neef, A.; Peretó, J.; Patiño-Navarrete, R.; Pignatelli, M.; Latorre, A.; Moya, A. Evolutionary convergence and nitrogen metabolism in Blattabacterium strain Bge, primary endosymbiont of the cockroach Blattella germanica. PLoS Genet. 2009, 5, e1000721. [CrossRef] [PubMed]

13. Moran, N.A. Accelerated evolution and Muller's rachet in endosymbiotic bacteria. Proc. Natl. Acad. Sci. USA 1996, 93, 2873-2878. [CrossRef] [PubMed]

14. Munson, M.A.; Baumann, P.; Kinsey, M.G. Buchnera gen. nov. and Buchnera aphidicola sp. nov., a taxon consisting of the mycetocyte-associated, primary endosymbionts of aphids. Int. J. Syst. Bacteriol. 1991, 41, 566-568. [CrossRef]

15. Dasch, G.A.; Weiss, E.; Chang Sept, K.P.C.N. Endosymbionts of insects. In Bergeys Manual of Systematic Bacteriology; Bergey, D.H., Krieg, N.R., Holt, J.G., Eds.; Williams and Willkins: Baltimore, MD, USA, 1984; Volume 1, pp. 811-833. ISBN 9780683041088.

16. Douglas, A.E. Nutritional interactions in insect-microbial symbioses: aphids and their symbiotic bacteria Buchnera. Annu. Rev. Entomol. 1998, 43, 17-37. [CrossRef] [PubMed]

17. Baumann, P.; Baumann, L.; Lai, C.Y.; Rouhbakhsh, D.; Moran, N.A.; Clark, M.A. Genetics, physiology, and evolutionary relationships of the genus Buchnera: intracellular symbionts of aphids. Annu. Rev. Microbiol. 1995, 49, 55-94. [CrossRef] [PubMed]

18. Shigenobu, S.; Watanabe, H.; Hattori, M.; Sakaki, Y.; Ishikawa, H. Genome sequence of the endocellular bacterial symbiont of aphids Buchnera sp. APS. Nature 2000, 407, 81-86. [CrossRef] [PubMed] 
19. Moran, N.A.; Munson, M.A.; Baumann, P.; Ishikawa, H. A molecular clock in endosymbiotic bacteria is calibrated using the insect hosts. Proc. R. Soc. B Biol. Sci. 1993, 253, 167-171. [CrossRef]

20. The International Aphid Genomics Consortium. Genome sequence of the pea aphid Acyrthosiphon pisum. PLOS Biol. 2010, 8, e1000313. [CrossRef]

21. Wilson, A.C.C.; Duncan, R.P. Signatures of host/symbiont genome coevolution in insect nutritional endosymbioses. Proc. Natl. Acad. Sci. USA 2015, 112, 10255-10261. [CrossRef] [PubMed]

22. Husnik, F.; Nikoh, N.; Koga, R.; Ross, L.; Duncan, R.P.; Fujie, M.; Tanaka, M.; Satoh, N.; Bachtrog, D.; Wilson, A.C.C.; et al. Horizontal gene transfer from diverse bacteria to an insect genome enables a tripartite nested mealybug symbiosis. Cell 2013, 153, 1567-1578. [CrossRef] [PubMed]

23. López-Madrigal, S.; Gil, R. Et tu, brute? Not even intracellular mutualistic symbionts escape horizontal gene transfer. Genes (Basel) 2017, 8, 247. [CrossRef] [PubMed]

24. Sloan, D.B.; Nakabachi, A.; Richards, S.; Qu, J.; Murali, S.C.; Gibbs, R.A.; Moran, N.A. Parallel histories of horizontal gene transfer facilitated extreme reduction of endosymbiont genomes in sap-feeding insects. Mol. Biol. Evol. 2014, 31, 857-871. [CrossRef] [PubMed]

25. Luan, J.B.; Chen, W.; Hasegawa, D.K.; Simmons, A.; Wintermantel, W.M.; Ling, K.S.; Fei, Z.; Liu, S.S.; Douglas, A.E. Metabolic coevolution in the bacterial symbiosis of whiteflies and related plant sap-feeding insects. Genome Biol. Evol. 2015, 7, 2635-2647. [CrossRef] [PubMed]

26. Tamas, I.; Klasson, L.; Canback, B.; Naslund, A.K.; Eriksson, A.S.; Wernegreen, J.J.; Sandström, J.P.; Moran, N.A.; Andersson, S.G. 50 million years of genomic stasis in endosymbiotic bacteria. Science 2002, 296, 2376-2379. [CrossRef] [PubMed]

27. van Ham, R.C.; Kamerbeek, J.; Palacios, C.; Rausell, C.; Abascal, F.; Bastolla, U.; Fernandez, J.M.; Jimenez, L.; Postigo, M.; Silva, F.J.; et al. Reductive genome evolution in Buchnera aphidicola. Proc. Natl. Acad. Sci. USA 2003, 100, 581-586. [CrossRef] [PubMed]

28. Perez-Brocal, V.; Gil, R.; Ramos, S.; Lamelas, A.; Postigo, M.; Michelena, J.M.; Silva, F.J.; Moya, A.; Latorre, A. A small microbial genome: the end of a long symbiotic relationship? Science 2006, 314, 312-313. [CrossRef] [PubMed]

29. Lamelas, A.; Gosalbes, M.J.; Moya, A.; Latorre, A. New clues about the evolutionary history of metabolic losses in bacterial endosymbionts, provided by the genome of Buchnera aphidicola from the aphid Cinara tujafilina. Appl. Environ. Microbiol. 2011, 77, 4446-4454. [CrossRef] [PubMed]

30. Reyes-Prieto, M.; Vargas-Chávez, C.; Latorre, A.; Moya, A. SymbioGenomesDB: A database for the integration and access to knowledge on host-symbiont relationships. Database 2015, 2015, bav109. [CrossRef] [PubMed]

31. Guo, J.; Hatt, S.; He, K.; Chen, J.; Francis, F.; Wang, Z. Nine facultative endosymbionts in aphids. A review. J. Asia Pac. Entomol. 2017, 20, 794-801. [CrossRef]

32. Sandström, J.P.; Russell, J.A.; White, J.P.; Moran, N.A. Independent origins and horizontal transfer of bacterial symbionts of aphids. Mol. Ecol. 2001, 10, 217-228. [CrossRef] [PubMed]

33. Russell, J.A.; Latorre, A.; Sabater-Munoz, B.; Moya, A.; Moran, N.A. Side-stepping secondary symbionts: widespread horizontal transfer across and beyond the Aphidoidea. Mol. Ecol. 2003, 12, 1061-1075. [CrossRef] [PubMed]

34. Oliver, K.M.; Smith, A.H.; Russell, J.A. Defensive symbiosis in the real world-Advancing ecological studies of heritable, protective bacteria in aphids and beyond. Funct. Ecol. 2014, 28, 341-355. [CrossRef]

35. Nikoh, N.; Tsuchida, T.; Maeda, T.; Yamaguchi, K.; Shigenobu, S.; Koga, R.; Fukatsu, T. Genomic insight into symbiosis-induced insect color change by a facultative bacterial endosymbiont, "Candidatus Rickettsiella viridis". MBio 2018, 9. [CrossRef] [PubMed]

36. Favret, C. Aphid Species File. Version 5.0/5.0. Available online: http://Aphid.SpeciesFile.org (accessed on 11 December 2018).

37. Jousselin, E.; Cœur D'Acier, A.; Vanlerberghe-Masutti, F.; Duron, O. Evolution and diversity of Arsenophonus endosymbionts in aphids. Mol. Ecol. 2013, 22, 260-270. [CrossRef] [PubMed]

38. Wulff, J.A.; Buckman, K.A.; Wu, K.; Heimpel, G.E.; White, J.A. The endosymbiont Arsenophonus is widespread in soybean aphid, Aphis glycines, but does not provide protection from parasitoids or a fungal pathogen. PLoS ONE 2013. [CrossRef] [PubMed] 
39. Zouari, S.; Ben Halima, M.K.; Reyes-Prieto, M.; Latorre, A.; Gil, R. Natural occurrence of secondary bacterial symbionts in aphids from Tunisia, with a focus on genus Hyalopterus. Environ. Entomol. 2018, 47, 325-333. [CrossRef] [PubMed]

40. Zytynska, S.E.; Weisser, W.W. The natural occurrence of secondary bacterial symbionts in aphids. Ecol. Entomol. 2016, 41, 13-26. [CrossRef]

41. Meseguer, A.S.; Manzano-Marín, A.; Coeur d'Acier, A.; Clamens, A.L.; Godefroid, M.; Jousselin, E. Buchnera has changed flatmate but the repeated replacement of co-obligate symbionts is not associated with the ecological expansions of their aphid hosts. Mol. Ecol. 2017, 26, 2363-2378. [CrossRef] [PubMed]

42. Burke, G.R.; Normark, B.B.; Favret, C.; Moran, N.A. Evolution and diversity of facultative symbionts from the aphid subfamily Lachninae. Appl. Environ. Microbiol. 2009, 75, 5328-5335. [CrossRef] [PubMed]

43. Chen, R.; Favret, C.; Jiang, L.; Wang, Z.; Qiao, G. An aphid lineage maintains a bark-feeding niche while switching to and diversifying on conifers. Cladistics 2016, 32, 555-572. [CrossRef]

44. Lamelas, A.; Perez-Brocal, V.; Gomez-Valero, L.; Gosalbes, M.J.; Moya, A.; Latorre, A. Evolution of the secondary symbiont "Candidatus Serratia symbiotica" in aphid species of the subfamily Lachninae. Appl. Environ. Microbiol. 2008, 74, 4236-4240. [CrossRef] [PubMed]

45. Manzano-Marín, A.; Szabó, G.; Simon, J.C.; Horn, M.; Latorre, A. Happens in the best of subfamilies: establishment and repeated replacements of co-obligate secondary endosymbionts within Lachninae aphids. Environ. Microbiol. 2017, 19, 393-408. [CrossRef] [PubMed]

46. Henry, L.M.; Maiden, M.C.J.; Ferrari, J.; Godfray, H.C.J. Insect life history and the evolution of bacterial mutualism. Ecol. Lett. 2015, 18, 516-525. [CrossRef] [PubMed]

47. Degnan, P.H.; Yu, Y.; Sisneros, N.; Wing, R.A.; Moran, N.A. Hamiltonella defensa, genome evolution of protective bacterial endosymbiont from pathogenic ancestors. Proc. Natl. Acad. Sci. USA 2009, 106, 9063-9068. [CrossRef] [PubMed]

48. Brady, C.M.; Asplen, M.K.; Desneux, N.; Heimpel, G.E.; Hopper, K.R.; Linnen, C.R.; Oliver, K.M.; Wulff, J.A.; White, J.A. Worldwide populations of the aphid Aphis craccivora are infected with diverse facultative bacterial symbionts. Microb. Ecol. 2014, 67, 195-204. [CrossRef] [PubMed]

49. Degnan, P.H.; Leonardo, T.E.; Cass, B.N.; Hurwitz, B.; Stern, D.; Gibbs, R.A.; Richards, S.; Moran, N.A. Dynamics of genome evolution in facultative symbionts of aphids. Environ. Microbiol. 2010, 12, 2060-2069. [CrossRef] [PubMed]

50. Tsuchida, T.; Koga, R.; Fujiwara, A.; Fukatsu, T. Phenotypic effect of "Candidatus Rickettsiella viridis," a Facultative symbiont of the pea aphid (Acyrthosiphon pisum), and Its interaction with a coexisting symbiont. Appl. Environ. Microbiol. 2014, 80, 525-533. [CrossRef] [PubMed]

51. Tsuchida, T.; Koga, R.; Horikawa, M.; Tsunoda, T.; Maoka, T.; Matsumoto, S.; Simon, J.-C.; Fukatsu, T. Symbiotic bacterium modifies aphid body color. Science 2010, 330, 1102-1104. [CrossRef] [PubMed]

52. Haynes, S.; Darby, A.C.; Daniell, T.J.; Webster, G.; Van Veen, F.J.; Godfray, H.C.; Prosser, J.I.; Douglas, A.E. Diversity of bacteria associated with natural aphid populations. Appl. Environ. Microbiol. 2003, 69, 7216-7223. [CrossRef]

53. Burke, G.R.; Moran, N.A. Massive genomic decay in Serratia symbiotica, a recently evolved symbiont of aphids. Genome Biol. Evol. 2011, 3, 195-208. [CrossRef] [PubMed]

54. de la Peña, E.; Vandomme, V.; Frago, E. Facultative endosymbionts of aphid populations from coastal dunes of the North Sea. Belgian J. Zool. 2014, 144, 41-50.

55. Manzano-Marín, A.; Simon, J.C.; Latorre, A. Reinventing the wheel and making it round again: evolutionary convergence in Buchnera-Serratia symbiotic consortia between the distantly related Lachninae aphids Tuberolachnus salignus and Cinara cedri. Genome Biol. Evol. 2016, 8, 1440-1458. [CrossRef] [PubMed]

56. Lamelas, A.; Gosalbes, M.J.; Manzano-Marín, A.; Peretó, J.; Moya, A.; Latorre, A. Serratia symbiotica from the aphid Cinara cedri: a missing link from facultative to obligate insect endosymbiont. PLoS Genet. 2011, 7, e1002357. [CrossRef] [PubMed]

57. Manzano-Marín, A.; Latorre, A. Settling down: the genome of Serratia symbiotica from the aphid Cinara tujafilina zooms in on the process of accommodation to a cooperative intracellular life. Genome Biol. Evol. 2014, 6, 1683-1698. [CrossRef] [PubMed]

58. Li, T.; Xiao, J.H.; Xu, Z.H.; Murphy, R.W.; Huang, D.W. A possibly new Rickettsia-like genus symbiont is found in Chinese wheat pest aphid, Sitobion miscanthi (Hemiptera: Aphididae). J. Invertebr. Pathol. 2011, 106, 418-421. [CrossRef] [PubMed] 
59. Li, T.; Xiao, J.H.; Xu, Z.H.; Murphy, R.W.; Huang, D.W. Cellular tropism, population dynamics, host range and taxonomic status of an aphid secondary symbiont, SMLS (Sitobion miscanthi L type symbiont). PLoS ONE 2011, 6, e21944. [CrossRef] [PubMed]

60. Fukatsu, T.; Tsuchida, T.; Nikoh, N.; Koga, R. Spiroplasma symbiont of the pea aphid, Acyrthosiphon pisum (Insecta: Homoptera). Appl. Environ. Microbiol. 2001, 67, 1284-1291. [CrossRef] [PubMed]

61. Wang, Z.; Shen, Z.R.; Song, Y.; Liu, H.Y.; Li, Z.X. Distribution and diversity of Wolbachia in different populations of the wheat aphid Sitobion miscanthi (Hemiptera: Aphididae) in China. Eur. J. Entomol. 2009, 106, 49-55. [CrossRef]

62. Augustinos, A.A.; Santos-Garcia, D.; Dionyssopoulou, E.; Moreira, M.; Papapanagiotou, A.; Scarvelakis, M.; Doudoumis, V.; Ramos, S.; Aguiar, A.F.; Borges, P.A.V.; et al. Detection and characterization of Wolbachia infections in natural populations of aphids: is the hidden diversity fully unraveled? PLOS ONE 2011, 6, e28695. [CrossRef] [PubMed]

63. de Clerck, C.; Tsuchida, T.; Massart, S.; Lepoivre, P.; Francis, F.; Jijakli, M.H. Combination of genomic and proteomic approaches to characterize the symbiotic population of the banana aphid (Hemiptera: Aphididae). Environ. Entomol. 2014, 43, 29-36. [CrossRef] [PubMed]

64. Jeyaprakash, A.; Hoy, M.A. Long PCR improves Wolbachia DNA amplification: wsp sequences found in $76 \%$ of sixty-three arthropod species. Insect Mol. Biol. 2000, 9, 393-405. [CrossRef] [PubMed]

65. Gomez-Valero, L.; Soriano-Navarro, M.; Perez-Brocal, V.; Heddi, A.; Moya, A.; Garcia-Verdugo, J.M.; Latorre, A. Coexistence of Wolbachia with Buchnera aphidicola and a secondary symbiont in the aphid Cinara cedri. J. Bacteriol. 2004, 186, 6626-6633. [CrossRef] [PubMed]

66. Guay, J.-F.; Boudreault, S.; Michaud, D.; Cloutier, C. Impact of environmental stress on aphid clonal resistance to parasitoids: Role of Hamiltonella defensa bacterial symbiosis in association with a new facultative symbiont of the pea aphid. J. Insect Physiol. 2009, 55, 919-926. [CrossRef] [PubMed]

67. Ferrari, J.; West, J.A.; Via, S.; Godfray, H.C.J. Population genetic structure and secondary symbionts in host-associated populations of the pea aphid complex. Evolution 2012, 66, 375-390. [CrossRef] [PubMed]

68. Moran, N.A.; Russell, J.A.; Koga, R.; Fukatsu, T. Evolutionary relationships of three new species of Enterobacteriaceae living as symbionts of aphids and other insects. Appl. Environ. Microbiol. 2005, 71, 3302-3310. [CrossRef] [PubMed]

69. Gil, R.; Silva, F.J.; Peretó, J.; Moya, A. Determination of the core of a minimal bacterial gene set. Microbiol. Mol. Biol. Rev. 2004, 68, 518-537. [CrossRef] [PubMed]

70. Gosalbes, M.J.; Lamelas, A.; Moya, A.; Latorre, A. The striking case of tryptophan provision in the cedar aphid Cinara cedri. J Bacteriol 2008, 190, 6026-6029. [CrossRef] [PubMed]

71. Iguchi, A.; Nagaya, Y.; Pradel, E.; Ooka, T.; Ogura, Y.; Katsura, K.; Kurokawa, K.; Oshima, K.; Hattori, M.; Parkhill, J.; et al. Genome evolution and plasticity of Serratia marcescens, an important multidrug-resistant nosocomial pathogen. Genome Biol. Evol. 2014, 6, 2096-2110. [CrossRef] [PubMed]

72. Sabri, A.; Leroy, P.; Haubruge, E.; Hance, T.; Frère, I.; Destain, J.; Thonart, P. Isolation, pure culture and characterization of Serratia symbiotica sp. nov., the R-type of secondary endosymbiont of the black bean aphid Aphis fabae. Int. J. Syst. Evol. Microbiol. 2011, 61, 2081-2088. [CrossRef] [PubMed]

73. Foray, V.; Grigorescu, A.S.; Sabri, A.; Haubruge, E.; Lognay, G.; Francis, F.; Fauconnier, M.-L.M.-L.; Hance, T.; Thonart, P. Whole-genome sequence of Serratia symbiotica strain CWBI-2.3T, a free-living symbiont of the black bean aphid Aphis fabae. Genome Announc. 2014, 2, e00767-14. [CrossRef] [PubMed]

74. Manzano-Marín, A.; Latorre, A. Snapshots of a shrinking partner: genome reduction in Serratia symbiotica. Sci. Rep. 2016, 6, 32590. [CrossRef]

75. Gil, R.; Latorre, A. Factors behind junk DNA in bacteria. Genes (Basel) 2012, 3, 634-650. [CrossRef] [PubMed]

76. Fukatsu, T.; Ishikawa, H. Phylogenetic position of yeast-like symbiont of Hamiltonaphis styraci (Homoptera, Aphididae) based on 18S rDNA sequence. Insect Biochem. Mol. Biol. 1996, 26, 383-388. [CrossRef]

77. Vogel, K.J.; Moran, N.A. Functional and evolutionary analysis of the genome of an obligate fungal symbiont. Genome Biol. Evol. 2013, 5, 891-904. [CrossRef] [PubMed]

78. Chong, R.A.; Moran, N.A. Evolutionary loss and replacement of Buchnera, the obligate endosymbiont of aphids. ISME J. 2018, 12, 898-980. [CrossRef] [PubMed]

79. Fukatsu, T.; Watanabe, K.; Sekiguchi, Y. Specific detection of intracellular symbiotic bacteria of aphids by oligonucleotide-probed in situ hybridization. Appl. Entomol. Zool. 1998, 33, 461-472. [CrossRef] 
80. Pyka-Fosciak, G.; Szklarzewicz, T. Germ cell cluster formation and ovariole structure in viviparous and oviparous generations of the aphid Stomaphis quercus. Int. J. Dev. Biol. 2008. [CrossRef] [PubMed]

81. Jousselin, E.; Clamens, A.L.; Galan, M.; Bernard, M.; Maman, S.; Gschloessl, B.; Duport, G.; Meseguer, A.S.; Calevro, F.; Coeur d'acier, A. Assessment of a $16 \mathrm{~S}$ rRNA amplicon Illumina sequencing procedure for studying the microbiome of a symbiont-rich aphid genus. Mol. Ecol. Resour. 2016, 16, 628-640. [CrossRef] [PubMed]

82. Urban, J.M.; Cryan, J.R. Two ancient bacterial endosymbionts have coevolved with the planthoppers (Insecta: Hemiptera: Fulgoroidea). BMC Evol. Biol. 2012, 12, 87. [CrossRef] [PubMed]

83. Moran, N.A.; Tran, P.; Gerardo, N.M. Symbiosis and insect diversification: an ancient symbiont of sap-feeding insects from the bacterial phylum Bacteroidetes. Appl. Environ. Microbiol. 2005, 71, 8802-8810. [CrossRef] [PubMed]

84. Wu, D.; Daugherty, S.C.; Van Aken, S.E.; Pai, G.H.; Watkins, K.L.; Khouri, H.; Tallon, L.J.; Zaborsky, J.M.; Dunbar, H.E.; Tran, P.L.; et al. Metabolic complementarity and genomics of the dual bacterial symbiosis of sharpshooters. PLoS Biol. 2006, 4, e188. [CrossRef] [PubMed]

85. Matsuura, Y.; Moriyama, M.; Łukasik, P.; Vanderpool, D.; Tanahashi, M.; Meng, X.-Y.; McCutcheon, J.P.; Fukatsu, T. Recurrent symbiont recruitment from fungal parasites in cicadas. Proc. Natl. Acad. Sci. USA 2018, 115, 5970-5979. [CrossRef] [PubMed]

86. Campbell, M.A.; Van Leuven, J.T.; Meister, R.C.; Carey, K.M.; Simon, C.; McCutcheon, J.P. Genome expansion via lineage splitting and genome reduction in the cicada endosymbiont Hodgkinia. Proc. Natl. Acad. Sci. USA 2015, 112, 10192-10199. [CrossRef] [PubMed]

87. Łukasik, P.; Nazario, K.; Van Leuven, J.T.; Campbell, M.A.; Meyer, M.; Michalik, A.; Pessacq, P.; Simon, C.; Veloso, C.; McCutcheon, J.P. Multiple origins of interdependent endosymbiotic complexes in a genus of cicadas. Proc. Natl. Acad. Sci. USA 2018, 115, 226-235. [CrossRef] [PubMed]

88. van Leuven, J.T.; Meister, R.C.; Simon, C.; McCutcheon, J.P. Sympatric speciation in a bacterial endosymbiont results in two genomes with the functionality of one. Cell 2014, 158, 1270-1280. [CrossRef] [PubMed]

89. Koga, R.; Moran, N.A. Swapping symbionts in spittlebugs: evolutionary replacement of a reduced genome symbiont. ISME J. 2014, 8, 1237-1246. [CrossRef] [PubMed]

90. McCutcheon, J.P.; Moran, N.A. Functional convergence in reduced genomes of bacterial symbionts spanning 200 My of evolution. Genome Biol. Evol. 2010, 2, 708-718. [CrossRef] [PubMed]

91. Woyke, T.; Tighe, D.; Mavromatis, K.; Clum, A.; Copeland, A.; Schackwitz, W.; Lapidus, A.; Wu, D.; McCutcheon, J.P.; McDonald, B.R.; et al. One bacterial cell, one complete genome. PLoS ONE 2010, 5, e10314. [CrossRef] [PubMed]

92. Bennett, G.M.; McCutcheon, J.P.; MacDonald, B.R.; Romanovicz, D.; Moran, N.A. Differential genome evolution between companion symbionts in an insect-bacterial symbiosis. MBio 2014, 5, e01697-14. [CrossRef]

93. Chang, H.-H.; Cho, S.-T.; Canale, M.C.; Mugford, S.T.; Lopes, J.R.S.; Hogenhout, S.A.; Kuo, C.-H. Complete genome sequence of "Candidatus Sulcia muelleri" ML, an obligate nutritional symbiont of maize leafhopper ( Dalbulus maidis ). Genome Announc. 2015, 3, e01483. [CrossRef] [PubMed]

94. Bennett, G.M.; Moran, N.A. Small, smaller, smallest: the origins and evolution of ancient dual symbioses in a phloem-feeding insect. Genome Biol. Evol. 2013, 5, 1675-1688. [CrossRef] [PubMed]

95. Bennett, G.M.; Abbà, S.; Kube, M.; Marzachì, C. Complete genome sequences of the obligate symbionts "Candidatus Sulcia muelleri" and "Ca. Nasuia deltocephalinicola" from the pestiferous leafhopper Macrosteles quadripunctulatus (Hemiptera: Cicadellidae). Genome Announc. 2016, 4, e01604-15. [CrossRef] [PubMed]

96. Mao, M.; Yang, X.; Poff, K.; Bennett, G. Comparative genomics of the dual-obligate symbionts from the treehopper, entylia carinata (Hemiptera:Membracidae), Provide insight into the origins and evolution of an ancient symbiosis. Genome Biol. Evol. 2017, 9, 1803-1815. [CrossRef] [PubMed]

97. Bennett, G.M.; Mao, M. Comparative genomics of a quadripartite symbiosis in a planthopper host reveals the origins and rearranged nutritional responsibilities of anciently diverged bacterial lineages. Environ. Microbiol. 2018, 20, 4461-4472. [CrossRef] [PubMed]

98. Noda, H.; Watanabe, K.; Kawai, S.; Yukuhiro, F.; Miyoshi, T.; Tomizawa, M.; Koizumi, Y.; Nikoh, N.; Fukatsu, T. Bacteriome-associated endosymbionts of the green rice leafhopper Nephotettix cincticeps (Hemiptera: Cicadellidae). Appl. Entomol. Zool. 2012, 47, 217-225. [CrossRef] 
99. Gonella, E.; Negri, I.; Marzorati, M.; Mandrioli, M.; Sacchi, L.; Pajoro, M.; Crotti, E.; Rizzi, A.; Clementi, E.; Tedeschi, R.; et al. Bacterial endosymbiont localization in Hyalesthes obsoletus, the insect vector of bois noir in Vitis vinifera. Appl. Environ. Microbiol. 2011, 77, 1423-1435. [CrossRef] [PubMed]

100. Gil, R. The minimal gene-set machinery. In Encyclopedia of Molecular Cell Biology and Molecular Medicine: Synthetic Biology, 2nd ed.; Meyers, R.A., Ed.; Wiley-VCH Verlag GmbH. \& Co.: Weinheim, Germany, 2015; Volume 2, pp. 443-478. ISBN 978-3-527-33482-7.

101. Takiya, D.M.; Tran, P.L.; Dietrich, C.H.; Moran, N.A. Co-cladogenesis spanning three phyla: leafhoppers (Insecta: Hemiptera: Cicadellidae) and their dual bacterial symbionts. Mol. Ecol. 2006, 15, 4175-4191. [CrossRef] [PubMed]

102. Brentassi, M.E.; Franco, E.; Balatti, P.; Medina, R.; Bernabei, F.; Marino de Remes Lenicov, A.M. Bacteriomes of the corn leafhopper, Dalbulus maidis (DeLong \& Wolcott, 1923) (Insecta, Hemiptera, Cicadellidae: Deltocephalinae) harbor Sulcia symbiont: molecular characterization, ultrastructure, and transovarial transmission. Protoplasma 2017, 254, 1421-1429. [CrossRef] [PubMed]

103. Bressan, A.; Arneodo, J.; Simonato, M.; Haines, W.P.; Boudon-Padieu, E. Characterization and evolution of two bacteriome-inhabiting symbionts in cixiid planthoppers (Hemiptera: Fulgoromorpha: Pentastirini). Environ. Microbiol. 2009, 11, 3265-3279. [CrossRef] [PubMed]

104. Song, N.; Liang, A.P. A Preliminary Molecular Phylogeny of Planthoppers (Hemiptera: Fulgoroidea) Based on Nuclear and Mitochondrial DNA Sequences. PLoS ONE 2013, 8, e58400. [CrossRef] [PubMed]

105. Marshall, D.C.; Moulds, M.; Hill, K.B.R.; Price, B.W.; Wade, E.J.; Owen, C.L.; Goemans, G.; Marathe, K.; Sarkar, V.; Cooley, J.R.; et al. A molecular phylogeny of the cicadas (Hemiptera: Cicadidae) with a review of tribe and subfamily classification. Zootaxa 2018, 4424, 1-64. [CrossRef] [PubMed]

106. Zahniser, J.N.; Dietrich, C. A review of the tribes of Deltocephalinae (Hemiptera: Auchenorrhyncha: Cicadellidae). Eur. J. Taxon. 2013, 45, 1-211. [CrossRef]

107. Tang, M.; Lv, L.; Jing, S.; Zhu, L.; He, G. Bacterial symbionts of the brown planthopper, Nilaparvata lugens (Homoptera: Delphacidae). Appl. Environ. Microbiol. 2010, 76, 1740-1745. [CrossRef] [PubMed]

108. Noda, H.; Koizumi, Y.; Zhang, Q.; Deng, K. Infection density of Wolbachia and incompatibility level in two planthopper species, Laodelphax striatellus and Sogatella furcifera. Insect Biochem. Mol. Biol. 2001, 31, 727-737. [CrossRef]

109. Kobiałka, M.; Michalik, A.; Walczak, M.; Szklarzewicz, T. Dual "bacterial-fungal" symbiosis in deltocephalinae leafhoppers (Insecta, Hemiptera, Cicadomorpha: Cicadellidae). Microb. Ecol. 2018, 75, 771-782. [CrossRef] [PubMed]

110. Hemmati, C.; Moharramipour, S.; Seyahooei, M.A.; Bagheri, A.; Mehrabadi, M. Identification of yeast and yeast-like symbionts associated with Hishimonus phycitis (Hemiptera: Cicadellidae), the insect vector of lime witches' broom phytoplasma. J. Crop Prot. 2017, 6, 439-446.

111. Michalik, A.; Jankowska, W.; Kot, M.; Gołas, A.; Szklarzewicz, T. Symbiosis in the green leafhopper, Cicadella viridis (Hemiptera, Cicadellidae). Association in statu nascendi? Arthropod Struct. Dev. 2014, 43, 579-587. [CrossRef] [PubMed]

112. Nishino, T.; Tanahashi, M.; Lin, C.P.; Koga, R.; Fukatsu, T. Fungal and bacterial endosymbionts of eared leafhoppers of the subfamily Ledrinae (Hemiptera: Cicadellidae). Appl. Entomol. Zool. 2016, 51, 465-477. [CrossRef]

113. Sasaki, T.; Kawamura, M.; Ishikawa, H. Nitrogen recycling in the brown planthopper, Nilaparvata lugens: involvement of yeast-like endosymbionts in uric acid metabolism. J. Insect Physiol. 1996, 42, 125-129. [CrossRef]

114. Koga, R.; Bennett, G.M.; Cryan, J.R.; Moran, N.A. Evolutionary replacement of obligate symbionts in an ancient and diverse insect lineage. Environ. Microbiol. 2013, 15, 2073-2081. [CrossRef] [PubMed]

115. Michalik, A.; Szwedo, J.; Stroiński, A.; Świerczewski, D.; Szklarzewicz, T. Symbiotic cornucopia of the monophagous planthopper Ommatidiotus dissimilis (Fallén, 1806) (Hemiptera: Fulgoromorpha: Caliscelidae). Protoplasma 2018, 255, 1317-1329. [CrossRef] [PubMed]

116. Kobiałka, M.; Michalik, A.; Walczak, M.; Junkiert, Ł.; Szklarzewicz, T. Sulcia symbiont of the leafhopper Macrosteles laevis (Ribaut, 1927) (Insecta, Hemiptera, Cicadellidae: Deltocephalinae) harbors Arsenophonus bacteria. Protoplasma 2016, 253, 903-912. [CrossRef] [PubMed] 
117. Ishii, Y.; Matsuura, Y.; Kakizawa, S.; Nikoh, N.; Fukatsua, T. Diversity of bacterial endosymbionts associated with macrosteles leafhoppers vectoring phytopathogenic phytoplasmas. Appl. Environ. Microbiol. 2013, 79, 5013-5022. [CrossRef] [PubMed]

118. Sacchi, L.; Genchi, M.; Clementi, E.; Bigliardi, E.; Avanzati, A.M.; Pajoro, M.; Negri, I.; Marzorati, M.; Gonella, E.; Alma, A.; et al. Multiple symbiosis in the leafhopper Scaphoideus titanus (Hemiptera: Cicadellidae): details of transovarial transmission of Cardinium sp. and yeast-like endosymbionts. Tissue Cell 2008, 40, 231-242. [CrossRef] [PubMed]

119. McCutcheon, J.P.; McDonald, B.R.; Moran, N.A. Convergent evolution of metabolic roles in bacterial co-symbionts of insects. Proc. Natl. Acad. Sci. USA 2009, 106, 15394-15399. [CrossRef] [PubMed]

120. Yamao, F. UGA is read as tryptophan in Mycoplasma capricolum. Proc. Natl. Acad. Sci. USA 1985, 82, $2306-2309$. [CrossRef] [PubMed]

121. Knight, R.D.; Landweber, L.F.; Yarus, M. How mitochondria redefine the code. J. Mol. Evol. 2001, 53, $299-313$. [CrossRef] [PubMed]

122. Campbell, M.A.; Łukasik, P.; Simon, C.; McCutcheon, J.P. Idiosyncratic genome degradation in a bacterial endosymbiont of periodical cicadas. Curr. Biol. 2017, 27, 3568-3575.e3. [CrossRef] [PubMed]

123. Thao, M.L.; Gullan, P.J.; Baumann, P. Secondary (gamma-Proteobacteria) endosymbionts infect the primary (beta-Proteobacteria) endosymbionts of mealybugs multiple times and coevolve with their hosts. Appl. Environ. Microbiol. 2002, 68, 3190-3197. [CrossRef]

124. von Dohlen, C.D.; Kohler, S.; Alsop, S.T.; McManus, W.R. Mealybug beta-proteobacterial endosymbionts contain gamma-proteobacterial symbionts. Nature 2001, 412, 433-436. [CrossRef] [PubMed]

125. McCutcheon, J.P.; Von Dohlen, C.D. An interdependent metabolic patchwork in the nested symbiosis of mealybugs. Curr. Biol. 2011, 21, 1366-1372. [CrossRef] [PubMed]

126. López-Madrigal, S.; Latorre, A.; Porcar, M.; Moya, A.; Gil, R. Complete genome sequence of “Candidatus Tremblaya princeps" strain PCVAL, an intriguing translational machine below the living-cell status. J. Bacteriol. 2011, 193, 5587-5588. [CrossRef] [PubMed]

127. López-Madrigal, S.; Latorre, A.; Porcar, M.; Moya, A.; Gil, R. Mealybugs nested endosymbiosis: going into the "matryoshka" system in Planococcus citri in depth. BMC Microbiol. 2013, 13, 74. [CrossRef] [PubMed]

128. Husnik, F.; McCutcheon, J.P. Repeated replacement of an intrabacterial symbiont in the tripartite nested mealybug symbiosis. Proc. Natl. Acad. Sci. USA 2016, 113, 5416-5424. [CrossRef] [PubMed]

129. Szabó, G.; Schulz, F.; Toenshoff, E.R.; Volland, J.M.; Finkel, O.M.; Belkin, S.; Horn, M. Convergent patterns in the evolution of mealybug symbioses involving different intrabacterial symbionts. ISME J. 2017, 11, 715-726. [CrossRef] [PubMed]

130. Baumann, L.; Thao, M.L.; Hess, J.M.; Johnson, M.W.; Baumann, P. The genetic properties of the primary endosymbionts of mealybugs differ from those of other endosymbionts of plant sap-sucking insects. Appl. Environ. Microbiol. 2002, 68, 3198-3205. [CrossRef]

131. López-Madrigal, S.; Latorre, A.; Moya, A.; Gil, R. The link between independent acquisition of intracellular gamma-endosymbionts and concerted evolution in Tremblaya princeps. Front. Microbiol. 2015, 6, 642. [CrossRef] [PubMed]

132. López-Madrigal, S.; Beltrà, A.; Resurrección, S.; Soto, A.; Latorre, A.; Moya, A.; Gil, R. Molecular evidence for ongoing complementarity and horizontal gene transfer in endosymbiotic systems of mealybugs. Front. Microbiol. 2014, 5, 449. [CrossRef] [PubMed]

133. Hardy, N.B.; Gullan, P.J.; Hodgson, C.J. A subfamily-level classification of mealybugs (Hemiptera: Pseudococcidae) based on integrated molecular and morphological data. Syst. Entomol. 2008, 33, 51-71. [CrossRef]

134. Gruwell, M.E.; Hardy, N.B.; Gullan, P.J.; Dittmar, K. Evolutionary relationships among primary endosymbionts of the mealybug subfamily Phenacoccinae (Hemiptera: Coccoidea: Pseudococcidae). Appl. Environ. Microbiol. 2010, 76, 7521-7525. [CrossRef] [PubMed]

135. Gil, R.; Vargas-Chavez, C.; López-Madrigal, S.; Santos-García, D.; Latorre, A.; Moya, A. Tremblaya phenacola PPER: an evolutionary beta-gammaproteobacterium collage. ISME J. 2018, 12, 124-135. [CrossRef] [PubMed]

136. Maréchal, A.; Brisson, N. Recombination and the maintenance of plant organelle genome stability. New Phytol. 2010, 186, 299-317. [CrossRef] [PubMed] 
137. Rice, D.W.; Alverson, A.J.; Richardson, A.O.; Young, G.J.; Sanchez-Puerta, M.V.; Munzinger, J.; Barry, K.; Boore, J.L.; Zhang, Y.; DePamphilis, C.W.; et al. Horizontal transfer of entire genomes via mitochondrial fusion in the angiosperm Amborella. Science 2013, 342, 1468-1473. [CrossRef] [PubMed]

138. Ankrah, N.Y.D.; Chouaia, B.; Douglas, A.E. The cost of metabolic interactions in symbioses between insects and bacteria with reduced genomes. MBio 2018, 9, e01433-18. [CrossRef] [PubMed]

139. Nakabachi, A.; Shigenobu, S.; Sakazume, N.; Shiraki, T.; Hayashizaki, Y.; Carninci, P.; Ishikawa, H.; Kudo, T.; Fukatsu, T. Transcriptome analysis of the aphid bacteriocyte, the symbiotic host cell that harbors an endocellular mutualistic bacterium, Buchnera. Proc. Natl. Acad. Sci. USA 2005, 102, 5477-5482. [CrossRef] [PubMed]

140. Hansen, A.K.; Moran, N.A. Aphid genome expression reveals host-symbiont cooperation in the production of amino acids. Proc. Natl. Acad. Sci. USA 2011, 108, 2849-2854. [CrossRef] [PubMed]

141. Masson, F.; Copete, S.C.; Schüpfer, F.; Garcia-Arraez, G.; Lemaitre, B. In vitro culture of the insect endosymbiont Spiroplasma poulsonii highlights bacterial genes involved in host- symbiont interaction. MBio 2018, 9, e00024-18. [CrossRef] [PubMed]

(C) 2019 by the authors. Licensee MDPI, Basel, Switzerland. This article is an open access article distributed under the terms and conditions of the Creative Commons Attribution (CC BY) license (http:/ / creativecommons.org/licenses/by/4.0/). 